\title{
Potential of Used Cooking Oil as Feedstock for Hydroprocessing into Hydrogenation Derived Renewable Diesel: A Review
}

\author{
Josiah Pelemo $^{1}$, Freddie L. Inambao ${ }^{2, *}$ and Emmanuel Idoko Onuh ${ }^{3}$. \\ ${ }^{1,2,3}$ Green Energy Solutions Research Group,Discipline of Mechanical Engineering, \\ University of KwaZulu-Natal,Durban 4041, South Africa.
}

${ }^{2}$ ORCID: 0000-0001-9922-5434 (Freddie Inambao)

\begin{abstract}
Feedstock is one of the key resources for the production of hydrogenation derived renewable diesel (HDRD). Used cooking oil is a waste oil generated from vegetable oil after frying and can be easily sourced from domestic, restaurant outlet and food processing industries within the Durban metropolis. The right selection of feedstock contributes to the high yield and quality of HDRD. Current works on several vegetable oil sources for potential feedstock applications are reviewed. Good quality and optimal yields of HDRD can be obtained by proper selection of potential feedstock, the right catalyst, and optimal process parameters for desirable reaction pathway etc. The literature on vegetable oil as potential feedstock is discussed. Literature regarding the selection of catalysts for hydrogenation is reviewed. Biomass-based thermal power plants fly ash (BBTPPFS) and calcium oxide sourced from eggshell are identified as viable catalysts for the HDRD process.
\end{abstract}

Keywords: Feedstock, green diesel, catalyst, hydroprocessing, compression ignition engine, used cooking oil .

\section{INTRODUCTION}

Energy demand is on the increase due to the improved quality of human life, population growth, and increased industrial development. Depletion of oil resources has led to a search for an alternative fuel that is sustainable and environmentally friendly. Fossil fuel and oil product pollution is on the increase. As governments address the global warming problem with strategies to bring it under control, the lawmakers have targeted pollution generated by transport. Despite the consistent efforts of governments and stakeholders to proffer lasting solutions to the energy crisis, global warming, and the rapid depletion of fossil fuel, the threat is still on the increase and is a major concern globally. The limited supply of biofuel both locally and internationally has affected economic growth. Researchers have been saddled with the task of searching for sustainable alternative fuels for the transportation sector in order to create a healthy environment for humans, plants and animals. Renewable energy is emerging as the only viable solution to the problem of environmental and fuel crises. The compression ignition $(\mathrm{CI})$ engine accounts for a significant percentage of energy-related greenhouse gas emissions worldwide, as shown in Fig. 1. Pollution in the sector is increasing faster than any other due to steady growth in the use of personal cars and the increase in industries in the developing world. Several researchers have reported the harmful effect of petroleumbased fuel emission and its role in damaging the environment. These challenges have compelled governments to gear their efforts towards investigating suitable alternatives fuel for petroleum products.

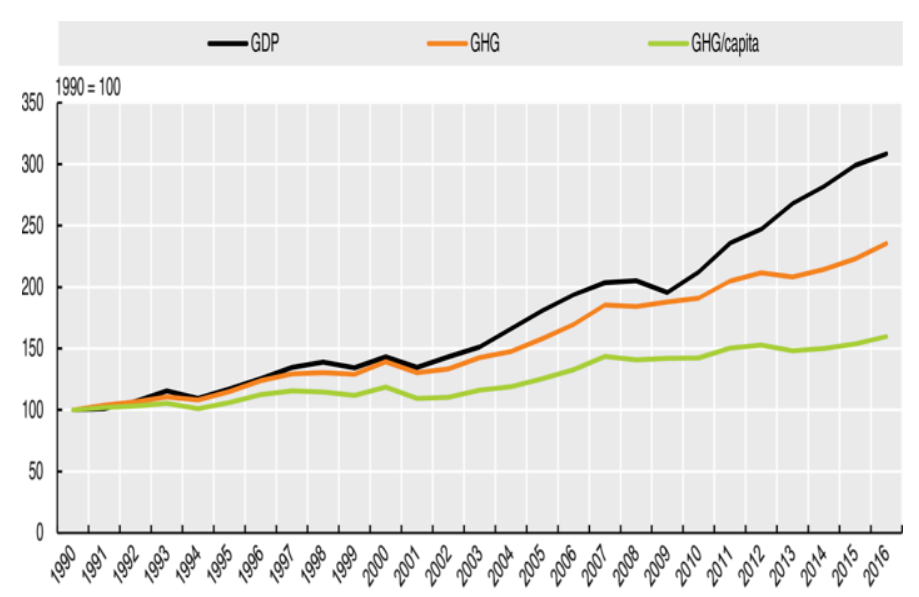

Fig. 1. The steady rise in greenhouse gas emissions due to global industrialization [1]

Prominent among the alternatives to fossil fuel available currently are biodiesel and green diesel. Biodiesel is a fatty acid methyl ester (FAME), which cannot be used directly for CI engines because of its high viscosity compared to conventional diesel. Biodiesel as an alternative transportation fuel comprises oxygenates and unsaturated $\mathrm{C}-\mathrm{C}$ bonds which pose some major challenges such as low oxidation stability, low freezing point, low calorific value, sulphur, oxygen, water and particles all of which pose significant challenges to $\mathrm{CI}$ engines. Generally, many researchers have reported that biodiesel limitations include degradation under storage, blockage of fuel filters, injectors, and hoses, higher nitrogen corrosive nature, extreme engine wear, poor (low) temperature operation (poor pour point and cloud point), composition of $\mathrm{O}_{2}$ and $\mathrm{H}_{2} \mathrm{O}$ and high kinematic viscosity $[2,3]$. Due to these shortcomings, biodiesel is blended with petrol-based diesel with proportions depending on the application. Hence, the need 
for a sustainable transport fuel at competitively cheap cost without the need for retrofitting of the CI engine. The properties of green diesel offered by hydrogenation derived renewable diesel (HDRD) make it a superior candidate in terms of high heating value, high energy density, high cetane value (80-90), and lower NOx emissions. This green diesel can be used directly without any modification in the CI engine or the fuel. However, access to cheap feedstock, a viable source of hydrogen and a catalyst with optimal performance remains a challenge.

What are the optimal pathways to the production of green diesel produced via hydroprocessing technology with the requisite fuel properties for CI application? Several production technologies have been developed to produce green diesel in recent times e.g. hydrodeoxygenation (HDO), deoxygenation (DO), and pyrolysis using fatty acid and triglycerides as feedstock. HDO is a process of removal of oxygen with the introduction of hydrogen gas under high pressure. DO involves the removal of oxygen from fatty acids or triglycerides under a hydrogen-free process. Pyrolysis involves the application of heat to convert biomass into gases, solid char and condensable pyrolytic vapor with higher value fuels (bio-oil). The production chain and logistics of distribution of biodiesel coupled with feedstock supply is capital intensive which raises the cost of biodiesel. The transportation sector accounts for the largest share of $63 \%$ and $1.1 \%$ of the total growth in world consumption of petroleum and other liquid fuels from 2010 to 2040 [4]. The South African Draft Strategy adopted a 5-year pilot program to achieve a $2 \%$ penetration level of biofuels or 400 million liters in the national liquid fuel supply [5] but this has not been achieved hence the need for a policy that will harness the technology, regular sources of feedstock and incentives to enhance the production of hydrogenation derived renewable diesel (HDRD). Concerted efforts have been made through the Biofuels Regulatory Framework (Act No. 34 of 2008) to commence the commercial production of renewable fuels, but not much has been achieved in that sector due to technical and economic factors [6]. In order to establish a sustainable production plan for HDRD products, a system that allows highly skilled personnel in related technology must be in place and government must be ready to provide incentives to reduce risk.

HDRD can be produced via a desulphurization unit of an existing refinery with basic modification of the catalyst bed [10]. In order to achieve a commercial production capacity, the Government must be willing to provide incentives to reach out to experts through the mechanism of the carbon credit/tax and implement a fuel levy subsidy as stipulated in the biofuel policy [7]. This review sets out to investigate all issues relevant to the optimal production of HDRD from used cooking oil (UCO) with the stated aim of identifying research gaps that, if explored, could be pivotal to the efficient domestication of this technology in sub-Saharan Africa.

\section{BACKGROUND AND HIGHLIGHTS OF HDRD}

HDRD has evolved as a technically feasible next-generation transportation fuel. This renewable energy form emerged because of the need for sustainable renewable fuel that is compatible with a CI engine without modification. Hence, the search for a fuel that is environmentally friendly and economically competitive, which is not the case for conventional biodiesel and fossil-derived diesel. Greenhouse gas (GHG) emissions from the energy sector and power production are increasing significantly and are the major causes of climate change. The second-largest source of GHG is motorized transportation [8]. According to the United States Environmental Protection Agency, carbon dioxide $\left(\mathrm{CO}_{2}\right)$ emissions (which are the major GHG associated with vehicle transportation) rose by $29 \%$ between 1990 and 2007 (EPA, April 25, 2009). Approximately $20 \%$ of the total $\mathrm{CO}_{2}$ currently released into the atmosphere is as a result of human activities such as transport-related emissions and they are expected to rise in the future. According to Specht [20], transportation utilizes petroleum-based products with gasoline making up more than $50 \%$ of the emissions with diesel and jet fuel contributing to the remainder.

Hydrogenation-derived renewable diesel (HDRD) is a promising alternative fuel due to its excellent low-temperature properties, cetane number $(\mathrm{CN})$, and similarity to biodiesel and fossil diesel. Hence, green diesel can be used as a drop-in fuel in current diesel engines.

Hydroprocessing is a well-known technology in the petroleum refining industry, and can be carried out either by hydrocracking technology or by the less severe hydrotreating technology. When these techniques are applied to oxygenated hydrocarbons, the removal of oxygen can be carried out by decarboxylation, decarbonylation, or HDO [9]. Hydroprocessing of vegetable oil leads to the production of hydrocarbons in the boiling range of diesel, and therefore it is commonly called green diesel or renewable diesel. The basic idea is to transform triglycerides in vegetable oil into high cetane hydrocarbons (mainly $n-\mathrm{C}_{17} \mathrm{H}_{36}$ and $n-\mathrm{C}_{18} \mathrm{H}_{38}$ ) by means of high pressure, high temperature, and a bifunctional catalyst (e.g., sulfide $\mathrm{NiMo} / \gamma-\mathrm{Al}_{2} \mathrm{O}_{3}$ ). Compared with biodiesel (fatty acids of methyl esters), green diesel, in general, has higher oxidation stability, lower specific gravity and higher $\mathrm{CN}$, and when it is blended with petroleum diesel it has much better cold flow properties. In addition, green diesel is totally compatible with petroleum diesel engines, thus retrofitting is not required.

The new technology for the production of green diesel, namely, HDO of triglycerides and fatty acids, compared to conventional hydrotreating catalysts, suffers from fast catalyst deactivation in the absence of hydrogen combined with high temperatures and high fatty acid content in the feedstock.

The commercialization of green diesel has commenced in recent times. Currently, some industries have embarked on green diesel production in Finland (Nestle oil) with two plants and a total capacity of 170000 tons/year [10]. The same company (Nestle oil) floated a commercial green diesel production firm in Rotterdam and Singapore in 2010 and 2011 respectively with a plant capacity of 800000 tons/year [11]. In 2009 Eco fining technology started converting vegetable oil using catalytic hydro processing [12]. The fuel has a high cetane value and can conveniently replace diesel fuel [12]. HBio/Petrobras constructed a hydrotreating unit to process 
vegetable oil and mineral diesel blends into green diesel that can be used as a diesel fuel enhancer which can reduce the sulphur content [12]. Table 1 shows green diesel production plants and capacity. Production of green diesel has witnessed slow advancement due to a lack of clear knowledge of the production technology of the process in South Africa. On the local scene not much is known regarding this field, so there are research gaps in the areas of processing conditions, feedstock selection, catalyst composition, catalyst hydrotreating/preconditioning and optimization of the reaction conditions. Furthermore, in order to make green diesel production more competitive with petrol-diesel locally, process economies need to be fully investigated.

Table I. Green diesel production plants and capacity [13]

\begin{tabular}{|c|c|c|c|c|c|c|}
\hline $\begin{array}{l}\text { Industry / } \\
\text { Location }\end{array}$ & $\begin{array}{l}\text { Cost of capital } \\
\text { investment } \\
\text { (USD) }\end{array}$ & Feedstock used & $\begin{array}{l}\text { Capacity } \\
\text { (ML/yr) }\end{array}$ & $\begin{array}{c}\text { Date of } \\
\text { commencement }\end{array}$ & Remarks & Ref \\
\hline $\begin{array}{l}\text { Nestle oil / Tuas, } \\
\text { singapore }\end{array}$ & 725 million & Palm oil & 906 & 2011 & Operational & [14] \\
\hline $\begin{array}{c}\text { Dynamics Fuels } \\
\text { (Syntroleum and } \\
\text { Tyson Foods joint } \\
\text { venture) Geismar, } \\
\text { Louisana }\end{array}$ & 150 million & $\begin{array}{c}\text { Soybean oil and } \\
\text { Animal fats }\end{array}$ & 283 & 2010 & Operational & [15] \\
\hline $\begin{array}{l}\text { Nestle Oil / } \\
\text { Netherlands, } \\
\text { Roterdam }\end{array}$ & 1 billion & $\begin{array}{c}\text { Rapeseed oil } \\
\text { Palm oil, Animal } \\
\text { fats }\end{array}$ & 906 & 2010 & Operational & [14] \\
\hline $\begin{array}{c}\text { Nestle oil/ } \\
\text { Finland, Porvoo }\end{array}$ & 130 million & $\begin{array}{l}\text { Rapeseed oil, } \\
\text { Animal fat, Palm } \\
\text { oil }\end{array}$ & 215 & 2009 & Operational & [16] \\
\hline $\begin{array}{c}\text { Nestle oil/ } \\
\text { Finland, Porvoo }\end{array}$ & 130 million & $\begin{array}{c}\text { Rapeseed oil, } \\
\text { Animal fats, Palm } \\
\text { oil. }\end{array}$ & 215 & 2007 & Operational & [16] \\
\hline $\begin{array}{l}\text { Valero and joint } \\
\text { venture, } \\
\text { /Louisiana, Norco }\end{array}$ & 300 million & $\begin{array}{l}\text { Soybean oil and } \\
\text { animal fats }\end{array}$ & 509 & $\begin{array}{l}\text { Proposed starting } \\
\text { date: } 2012\end{array}$ & $\begin{array}{c}\text { Under } \\
\text { construction }\end{array}$ & [17] \\
\hline $\begin{array}{l}\text { UPM biofuels/ } \\
\text { Finland, } \\
\text { Lappeenranta }\end{array}$ & 200 million & Tallow oil & 117 & $\begin{array}{l}\text { Proposed starting } \\
\text { date: } 2014\end{array}$ & $\begin{array}{l}\text { Construction } \\
\text { begins } 2012\end{array}$ & {$[18]$} \\
\hline
\end{tabular}

Total existing capacity 2,525 ML / yr

Total existing + Future capacity (Firm) 3,035 ML/ yr

Total existing + Future capacity (Possible) 3,151 ML / yr

Green diesel is a potential and promising renewable energy that can solve environmental and economic problems. Furthermore, green diesel can be produced in large volumes at existing centralized petroleum refineries. Green diesel or renewable diesel is a mixture of diesel-like hydrocarbons produced via a catalytic reaction involving hydroprocessing and/or decarboxylation/decarbonylation of triglycerides from various feedstocks [19]. While HDO eliminates oxygen by reacting triglycerides and FFAs with hydrogen to form water and nparaffins, decarboxylation or decarbonylation eliminates oxygen to form carbon dioxide or carbon monoxide and nparaffins [20]. This leads to a diesel product that is indistinguishable from petroleum diesel, while biodiesel is chiefly composed of oxygenated species that can have vastly different properties compared to traditional petroleum diesel [19]. HDRDs are lipid-derived liquid transportation biofuels and do not contain oxygen-based molecules. This characteristic of green diesel results in high heating value and high energy density [21]. The selection of feedstock that will offer optimal yield with low production cost is a critical step [22]. Therefore, there is a need to investigate suitable and available feedstocks, identify local and cheap catalyst sources, and the key parameters that will yield the best outcome for HDRD production in South Africa. 


\section{FEEDSTOCK OPTIONS}

The triglycerides and fatty acids found in vegetable oil are promising feedstocks for the production of renewable and sustainable biofuel. These feedstocks can produce diesel and gasoline-range hydrocarbons via hydroprocessing [23]. Green diesel is produced by hydroprocessing of triglycerides contained in feedstocks such as vegetable oils (e.g. rapeseed, soybean, cottonseed, palm, corn, sunflower, coconut, peanut, camelina, carinata, and jatropha oils), fats, micro-algal oils and UCOs [24]. These vegetable oils cannot be used directly in the modern CI engine due to their high viscosity but can be used as a green source after some modification of fuel properties [22]. Table 2 shows the current potential feedstock for HDRD production worldwide. Sunflower oil constitutes about $40 \%$ to $50 \%$ of vegetable oil production in Ukraine, Turkey, the
Russian Federation, Argentina, and Europe. The prominent sources of feedstock for biofuel in Europe are sunflower and rapeseed oils [25]. The percentages of production of vegetable oils across the globe are sunflower $(10 \%)$, rapeseed $(55 \%)$, cottonseed (10\%) and soybean (55\%) [26]. Malaysia has developed palm oil as a source of feedstock for renewable energy production [27, 28].

Feedstocks sourced from edible oils for the production of biofuel has become practically impossible due to the high cost of food and threats to food security. The requirement for large land spaces for cultivation, planting and harvesting, the threat of deforestation and the high cost of farming are major challenges facing edible oil. UCO as a feedstock for HDRD application has been adopted in recent times.

Table II. Current Potentials Feedstocks for green diesel production worldwide [29]

\begin{tabular}{|c|c|c|}
\hline $\mathbf{S} / \mathbf{N}$ & FEEDSTOCKS & WORLDWIDE \\
\hline 1 & Animal fat and waste oil & Mexico \\
\hline 2 & Rapeseed & Germany \\
\hline 3 & Rapeseed, Animal fat, Yellow grease /tallow, Soybeans/mustard & Canada \\
\hline 4 & Waste plastic oil/waste tyre oil/sunflower, Peanut/Jatropha /kangara & Indian \\
\hline 5 & waste oil/ Soybeans, Peanut & USA \\
\hline 6 & Rapeseed, sunflower, Waste plastic & Italy \\
\hline 7 & sunflower/ Rapeseed & France \\
\hline 8 & Cottonseed & Greece \\
\hline 9 & Rapeseed & Sweden \\
\hline 10 & Animal fat/ Frying oil & Ireland \\
\hline 11 & Palm oil & Malaysia \\
\hline 12 & Waste cooking oil/ Rapeseed & $\mathbf{U K}$ \\
\hline 13 & Waste cooking oil/Tallow & New Zealand \\
\hline 14 & Waste cooking oil & Japan \\
\hline 15 & Rapeseed /Waste cooking oil /Jatropha & China \\
\hline 16 & Frying oil/Animal fat & Ireland \\
\hline 17 & Soybeans & Argentina \\
\hline 18 & Jatropha /Palm oil/Coconut & Thailand \\
\hline 19 & Palm oil & Singapore \\
\hline 20 & Soybeans, Cottonseed, Palm oil, Castol oil & Brazil \\
\hline 21 & Jatropha, Coconut & Phillipine \\
\hline 22 & Palm oil, Coconut,Jatropha & Indonesia \\
\hline
\end{tabular}


The cheapest source of feedstock for the production of HDRD is UCO [30]. Rocha Filho et al. reported that more than 200000 tons of used cooking oil is generated in South Africa per/annum [31, 32]. Given the yield rate of $80 \%, 205$ million litres of HDRD could be produced annually from this waste. This would supply $1 \%$ of the $2 \%$ set aside for the renewable fuel in the biofuel policy of the government of South Africa. The current price of UCO is R3 / and diesel is R14 /l, therefore a value-added industry generating R2.04 billion can be created producing premium diesel (HDRD) along with the creation of thousands of jobs. Other potential secondary sources of feedstock are cellulosic waste from pulp and paper industries plus a diverse range of agricultural waste with a far greater capacity than UCO [7].

UCO is an oil generated from vegetable oils after frying and is abundant and readily available in food processing industries, restaurants, households, and fast food outlets. UCO is the second most abundant waste residue which is generated in enormous quantities every day. The global demand for edible vegetable oil is on the increase. Research indicates that annual consumption of edible oils in China is approaching 22 million tons; the country produces more than 4.5 million tons of used oil and grease per year [33]. Vegetable oil used for frying undergoes various physical and chemical changes, with some undesirable compounds like free fatty acids and polymerized triglycerides being formed during frying which causes a rise in molecular mass and condenses the volatility of the oil. UCO is a renewable resource and does not contain any aromatics, metal or sulphur contaminants. Reuse of UCO can exacerbate environmental problems and health challenges including hypertension, diabetes, and vascular inflammation [34]. Vegetable oil can be used for frying a variety of food items including chicken, beef, yam/potatoes. Currently, one of the barriers to renewable fuel commercialization is the high cost of feedstock compared to petroleum-based diesel. It has been established from literature that approximately $70 \%$ to $85 \%$ of the production costs of green diesel arise from the cost of raw materials. Therefore, application of UCO as a feedstock for processing of HDRD will reduce the production cost as it is available at a significantly lower price. The HDRD production process involves conversion of fatty acids in triglycerides into normal and/or iso-paraffin which can be obtained by HDO, decarbonylation, decarboxylation, isomerization and hydrocracking or a combination of two or more thereof.

UCO possesses high acid value due to the high content of free fatty acids [32]. In recent years, several petroleum companies have directed their resources into the production of renewable green fuels from hydroprocessing of vegetable oil feedstock, setting in motion a tremendous commercialisation process.

The Neste Oil Co. has developed a technology to produce highquality hydrocarbon from vegetable oils and animal fats. The NExBTL technology process produces green diesel by hydrotreating vegetable oils or waste animal fats. Neste Oil has opened a plant in Singapore using NExBTL technology with a plan to produce over 800000 tons renewable diesel per annuum from feedstocks [35]. The characterisation of the product by engine and automotive manufacturers using NExBTL has shown a high cetane value of between 84 and 99, low cloud point value (as low as $30{ }^{\circ} \mathrm{C}$ below zero), and the ability to withstand storage for extended periods. These properties enhance the performance of both car and truck engines [36].

The UOP/Eni Ecofining process is primarily based on hydrotreating of triglycerides and free fatty acids which gives DO via HDO and decarboxylation as outcomes [37, 38]. The next step after hydrotreating is an isomerization process step which is performed to obtain isoparaffin rich diesel fuel with good cold flow properties and the same chemical properties as Petro diesel. The renewable diesel product by the Ecofining process has been reported by life cycle assessment (2009) to be economically and environmentally competitive with biodiesel production [39]. UOP Honeywell Co. with its 90 years of refining technology experience is offering an alternative process to produce green fuels from various bio-feedstocks. The UOP/ENI Ecofining process [40] has been designed to convert non-edible oils to renewable diesel, which is applicable in any percentage in the existing fuel tanks, trucks, pipelines and automobile engines without modification.

Tyson Foods Inc. has commenced operations at a renewable diesel production plant in Geismar, LA, USA, for the production of green diesel through hydrotreating of non-edible grade animal fats including chicken fat, beef tallow and pork lard. Tyson and Syntroleum Corporation have created a joint venture which has developed a technology to produce synthetic fuels targeting the green diesel, jet, and military fuel markets. Syntroleum reported that the renewable diesel produced at the plant is $75 \%$ less in volume than that of petroleum diesel. The plant was designed to produce up to 75 million gallons of renewable diesel fuel per year [41]

Haldor Topsøe developed a new hydrotreating technology for production of green diesel and jet fuel from raw tallow. The feedstock used was a non-edible material, hence, the problems of global food shortage are not affected. Preem Gothenburg Sweden Refinery has adopted the technology which has been completed by Topsøe [42].

ConocoPhillips opened a commercial production plant for hydrogenation of vegetable oils to obtain renewable diesel fuel components that meet European Union standards at the company's Whitegate Refinery in Cork, Ireland. The HDRD is produced using existing equipment at the refinery and is being blended and transported with Petrodiesel. The refinery is producing 365000 barrels per anum of green diesel fuel for sale into the Irish market. The report of the tests conducted by ConoPhillip indicated that HDRD burns cleaner than petrol diesel, is sulfur free and emits less $\mathrm{NO}_{\mathrm{X}}[42]$.

Valero Energy Corporation has developed a plant at St Charles Refinery in Norco LA which is converts UCO and animal fat into renewable diesel via hydrogenation and isomerization processes [43] The fat and oil feedstocks are supplied by Darling International which is Valero's partner in the venture.

Toyota Motor Corporation (TMC), Hino Motors, the Tokyo Metropolitan Government and Nippon Oil Corporation (NOC) started a joint project aimed at commercializing bio hydrofined diesel (BHD), a second-generation renewable diesel fuel produced by hydrogenating a vegetable oil feedstock. Nippon Oil and Toyota have worked jointly on the development of 
International Journal of Engineering Research and Technology. ISSN 0974-3154 Vol.13, No.3 (2020), pp. 500-519

(C) International Research Publication House. https://dx.doi.org/10.37624/IJERT/13.3.2020.500-519

BHD technology since 2005. The use of refinery-based hydrogenation processes to produce a synthetic, secondgeneration renewable diesel is driven by several issues, including some technical considerations regarding the properties and effects of first-generation fatty acid methyl ester biodiesel (storage, oxidation, possible effect on fuel handling systems). In its studies, Nippon Oil explored reaction temperatures ranging from $240{ }^{\circ} \mathrm{C}$ to $360{ }^{\circ} \mathrm{C}$, with reaction pressures of $6 \mathrm{MPa}$ and $10 \mathrm{MPa}$, and used a common hydrodesulfurization catalyst. The resulting fuel is claimed to be aromatics- and sulfur-free, with a $\mathrm{CN}$ of 101 [42].

Table 3 shows the annual volume of used cooking oil collection in some countries; about 200000 tons of UCO not collected is disposed of in South Africa which contributes to soil and water contamination, sewage blockages, and damage to aquatic life [23].

Table III. The annual collection of Used Cooking Oil (UCO) (Million tons)

\begin{tabular}{|c|c|}
\hline Country & UCO Collection (Million tons) \\
\hline South Africa & 0.6 \\
\hline UK & 0.2 \\
\hline China & 5.0 \\
\hline Canada & 0.14 \\
\hline Malaysia & 0.5 \\
\hline
\end{tabular}

The consumption rate of vegetable oil has witnessed a tremendous increase globally (13). Most of these vegetable oils are used for frying and cooking by restaurants, fast-food outlets, and households. The annual collection of used cooking oils as shown in Table 3 is an estimate of the UCO collected in some countries. About 125000 and 140000 tons of UCO is generated per annum in Canada [44, 45]. In South African 0.6 million tons of UCO is collected annually from bakeries, takeaway outlets, and restaurants. [46, 47]. The UK and the European Union countries produced 0.7 tons to 1.0 tons and 0.2 tons of UCO per annum, respectively [48]. Apart from the cost-benefit of using UCO as a feedstock, it is also available and sustainable. Research shows that UCO contributed $17 \%$ and $9 \%$ of the feedstock for the production of 11.92 million tons and 26.62 million tons of renewable energy globally in 2015 [49].

The chemical composition of UCO has been investigated; revealing the following predominant chemical properties of the fatty acids in UCO: palmitic acid $38.35 \%$, oleic acid $43.67 \%$, linoleic acid $11.39 \%$ [50]. The fatty acids and properties of UCO make them viable as potential feedstock for hydrogenation. Table 4 shows the properties of UCO samples of sunflowers oil, palm oil and sunfoil.
Table IV. Properties of HDRD over another Biofuel [49]

\begin{tabular}{|l|c|c|c|}
\hline Properties & \multicolumn{3}{|c|}{ Used Cooking Oils Samples } \\
\hline & Sunflowers & Palm oil & Sunfoil \\
\hline Density $(\mathrm{Kg} / \mathrm{m} 3)$ & 920.4 & 913.4 & 923.2 \\
\hline $\mathrm{pH}$ value & 5.34 & 6.19 & 6.61 \\
\hline Viscosity $\left(\mathrm{mm}^{2} / \mathrm{s}\right)$ & 31.381 & 38.407 & 35.236 \\
\hline Acid value & 2.29 & 1.13 & 1.44 \\
\hline Congealing temp. ${ }^{0} \mathrm{C}$ & -5.15 & 14.7 & -3.4 \\
\hline Molecular wt. $(\mathrm{g} / \mathrm{mol})$ & 51.94 & 586.05 & 395.28 \\
\hline Iodine value $(\mathrm{cg} / \mathrm{g})$ & 111.1 & 54.2 & 54.2 \\
\hline
\end{tabular}

Feedstock plays an important role in determining production costs; using UCO as a feedstock can change the prices or break the profitability of an HDRD operation. Vegetable oil feedstocks cost makes up approximately $80 \%$ of the total production expenses and hydrogen and utilities make up approximately $15 \%$ [32] of biofuel. UCO is very cheap, requires little effort to source, and offers a good yield when used. Green diesel is oxygen-free, hence oxidation stability is high, it is non-corrosive and has a high heating value similar to petroleum-based diesel. Green diesel has superior stability in cold weather compared to biodiesel, it does not increase $\mathrm{NO}_{\mathrm{X}}$ emissions, and it has a higher $\mathrm{CN}$ which aids ignition in $\mathrm{CI}$ engines. Furthermore, green diesel produced by the hydroprocessing of triglycerides has propane as a by-product which is a gaseous fuel of good market value. This property makes green diesel production more attractive in economic terms when compared to the production of biodiesel [51]. Preparation of UCO is a critical stage in achieving a standard biofuel product, hence there is a gap regarding investigation of preparation protocols for UCO as a feedstock for production of green diesel.

\section{HYDROGENATION DERIVED RENEWABLE DIESEL (HDRD) AS AN ALTERNATIVE FUEL FOR COMPRESSION IGNITION ENGINE}

There is a pressing need to develop a new technology that is capable of converting vegetable oils into high-quality diesel fuel or diesel blend that is fully compatible with the CI engine. The new technology needs to be capable of utilizing widely available vegetable oil feedstock to produce renewable energy with a high cetane, low gravity, aromatics- and sulphur-free biofuel. The production process under consideration involves the conversion of fatty acids in triglycerides into alkanes which can be obtained by hydrogenation, decarboxylation, decarbonylation, isomerization, and hydrocracking.

Hydrotreating technology is a prominent technique in a refinery to remove $\mathrm{S}, \mathrm{N}$, and metals from petroleum-derived feedstock including heavy gas-oil or vacuum gas-oil [52]. Furthermore, catalytic hydrotreating is an effective technology with various applications in the petrochemical industry that has recently adopted and expanded into bio-oil upgrading. The hydrotreating process is beneficial because the required 
infrastructure is widely available in refinery units. By means of hydrotreating processes, a deoxygenated product is obtained with high oxidation stability and low sulphur content which is fully compatible with a CI engine. Hydrotreating also offers more benefits compared to the transesterification process of FAME due to its lower cost, compatibility with CI engine, $\mathrm{NO}_{\mathrm{X}}$ emission reduction, and feedstock flexibility.

DO technology involves managing the oxygenated compounds in the feedstock which have an effect on chemical stability and energy content of the biofuel. Renewable energy has a higher degree of stability and excellent combustion properties which can be obtained by the DO process through a reaction that includes decarbonylation, dehydration, and decarboxylation. The decarbonylation process aims at removing carbonyl groups from the hydrocarbon to reduce its heating value and improve its oxidation stability. In the dehydration process oxygen is removed in the form of water. Decarboxylation is a process that involves removal of oxygen from carboxylates, in order to make it more suitable for producing diesel with reduced acidity.

HDO is a process for the production of HDRD through the removal of oxygenated compounds from feedstock. The process requires a feedstock which contains oxygenated compounds and double bonds which can be converted into biofuel through the saturation of the double bonds and the removal of oxygen. In the HDO process high temperatures and pressures are required in the presence of hydrogen [53, 54]. High water content in biofuel is a challenge, therefore DO has an advantage in terms of economic and quality product yield.

The processes of hydrotreatment consists of two main stages. The first stage involves conversion of triglycerides to oxygenfree hydrocarbons (normal paraffin). The product in the first stage contains poor cold flow and low $\mathrm{CN}$ which is not suitable as transportation fuel. The hydro processing stage furthers the process to obtain normal paraffin by isomerization/dewaxing to obtain optimum iso-paraffin fuel with good cold flow properties. The hydrotreatment of liquid feedstocks occur when high temperatures and pressures are induced over a catalytic material using hydrogen.

Hydroprocessing of triglycerides to hydrocarbon products depends on some process reactions [55]. The process is achieved by the reactions during the conversion of triglycerides over a selected catalyst in a high-pressure atmosphere of $\mathrm{H}_{2}$. Insufficient $\mathrm{H}_{2}$ results in coke formation on the catalyst surface and catalyst deactivation. As a result, the green diesel yield will decrease and the profile of the green diesel species changes [56]. Hydroprocessing techniques are clearly a better choice of production route, but the best approach on how to adopt it in process design is not yet defined. The two choices available to be considered are: standalone unit reactor and co-processing in an existing hydroprocessing unit reactor. Co-processing is clearly an attractive option for refinery applications, since an existing refinery facility can be harnessed for HDRD application. Vegetable oil feedstocks contain trace metals and impurities such as phosphorus, potassium, calcium, and sodium which requires a seperate reactor to hydrotreat the vegetable oils for proper removal of all the contaminants. Another challenge is that the volume of catalyst in the existing reactor will not be sufficient for treating the catalyst and the thermal reaction that exists requires a device that can turn it off which is not available in the reactor. The DO products $\left(\mathrm{H}_{2} \mathrm{O}, \mathrm{CO}\right.$, $\mathrm{CO}_{2}$ ) require a revamping of the recycle gas system for removal or use of a substantial purge stream. Therefore, a large size standalone reactor unit dedicated to UCO is considered to be more cost-effective and has the potential for producing high yield of hydrocarbons.

The production of green diesel depends on the choice of processing pathways. HDRD is produced via a hydroprocessing pathway with propane, carbon monoxide (CO) and carbon dioxide $\left(\mathrm{CO}_{2}\right)$ as by-products. Fig. 2 and Fig. 3 show the production pathways for both HDRHs.

In the process shown in Fig. 2, the feedstock is mixed with hydrogen with a reaction temperature and pressure of $330^{\circ}$ to $360{ }^{\circ} \mathrm{C}$, and oxygen is removed at the DO unit in the form of water and is then sent to the isomerization reactor where the vegetable oil is converted from n-paraffins to iso-paraffins with cracking to naphtha and gas. Cloud point can be varied with lower cloud point producing higher naphtha yield where the $\mathrm{CN}$ is less than 70 .

The product is separated from the recycle gas in the product separator unit where the green diesel and by-product are collected.

Green diesel development has numerous and some basic benefits over FAME production processes in a refinery setup. The hydrogen required for the process is available in the refinery and does not require any special handling. The products can also be easily blended with conventional refinery products.

$$
\text { Triglycerides }+\mathrm{H}_{2}====>\text { Green Diesel }+\mathrm{H}_{2} \mathrm{O} / \mathrm{CO}_{2}+\text { Propane }
$$$$
100 \mathrm{bbl} \quad \text { Catalyst } 99 \mathrm{bbl} \quad 9 \mathrm{bbl}
$$

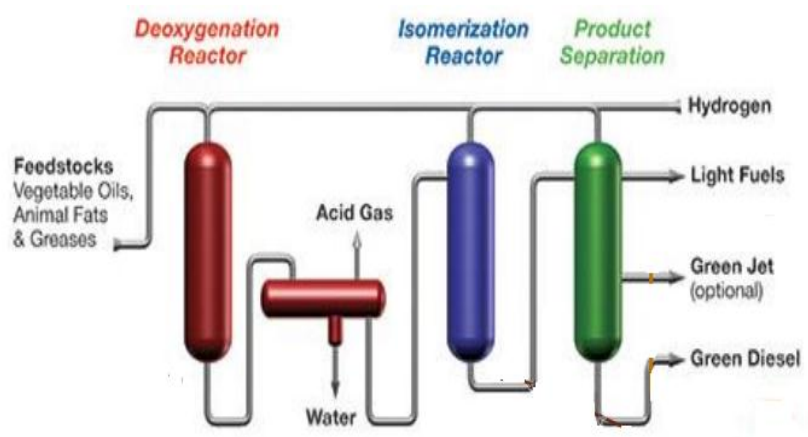

Fig. 2. Production process of green diesel [57]

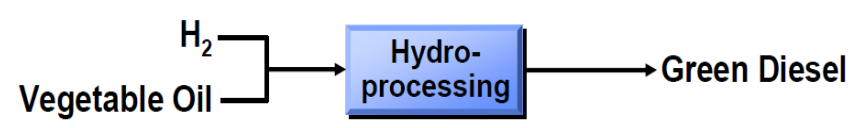

Fig. 3. Vegetable oil processing routes

Free Fatty Acid (FFA) content is not a problem for HDRD production because FFAs can easily be converted to paraffin [10]. Table 5 shows some properties of HDRD over petrolbased diesel and biodiesel. 
International Journal of Engineering Research and Technology. ISSN 0974-3154 Vol.13, No.3 (2020), pp. 500-519

(C) International Research Publication House. https://dx.doi.org/10.37624/IJERT/13.3.2020.500-519

Table V. Properties of HDRD over another Biofuel [58]

\begin{tabular}{|l|l|c|c|c|}
\hline S/N & Properties & Petrol based diesel & Biodiesel (FAME) & Green diesel \\
\hline $\mathbf{1}$ & Carbon, Wt\% & 86.8 & 76.2 & 84.9 \\
\hline $\mathbf{2}$ & Hydrogen, Wt\% & 13.2 & 12.6 & 15.1 \\
\hline $\mathbf{3}$ & Oxygen\% & 0.0 & 11.2 & 0.0 \\
\hline $\mathbf{4}$ & Specific gravity & 0.85 & 0.88 & 0.78 \\
\hline $\mathbf{5}$ & Cetane Number & $40-45$ & $45-55$ & $70-90$ \\
\hline $\mathbf{6}$ & T90, ${ }^{\circ} \mathrm{C}$ & $300-330$ & $330-360$ & $290-300$ \\
\hline $\mathbf{7}$ & Viscosity, mm ${ }^{2} / \mathrm{sec}$. @ 40 ${ }^{\circ} \mathrm{C}$ & $2-3$ & $4-5$ & $3-4$ \\
\hline & Energy content(LHV) & & & 44 \\
\hline $\mathbf{8}$ & Mass basis,MJ/KG & 43 & 16600 & 18900 \\
\hline $\mathbf{9}$ & Mass basis BTU/LB & 1850 & 121 & 122 \\
\hline $\mathbf{1 0}$ & Volume basis BTU/gal & 130 & & \\
\hline
\end{tabular}

HDRD can be produced from virtually any type of bio-based renewable feedstock; the advantage of the HDRD production process is that it makes use of existing refining technology and can be blended into the conventional diesel pool in very high concentrations, up to $100 \%$, with little or no adverse effects. Table 6 shows some studies on the reactor type, feedstock, catalyst, and process parameters.

Table VI Examples of Reactors and Process Parameter for HDRD Production

\begin{tabular}{|c|c|c|c|c|c|c|c|c|}
\hline S.No & Reactor & Feedstock & Catalyst & Temp.(k) & Time(h) & Press. (MPa) & Remark & Ref. \\
\hline 1 & Trickled-bed & $\begin{array}{l}\text { Crude palm } \\
\text { oil }\end{array}$ & $\mathrm{NiMo} / \mathrm{Al}_{2} \mathrm{O}_{3}$ & $533-613$ & $\mathrm{LHSV}=1 \mathrm{~h}^{-1}$ & $40-90$ & $\begin{array}{l}\text { Catalyst showed slight } \\
\text { deactivation }\end{array}$ & [59] \\
\hline 2 & Fixed bed & $\begin{array}{l}\text { Vegetable } \\
\text { and jatropha } \\
\text { oil }\end{array}$ & $1 \%$ pt/H-ZSM-5 & $543-573$ & LHSV $=1-2 h-^{1}$ & $\begin{array}{l}65,86 \% \mathrm{H}_{2} \text { in } \\
\mathrm{N}_{2}\end{array}$ & $\begin{array}{l}67 \%{ }^{\prime} \mathrm{C}_{15}-\mathrm{C}_{18} \\
\mathrm{Re} / \mathrm{Al}_{2} \mathrm{O}_{3}\end{array}$ & [60] \\
\hline 3 & Fixed bed & Rapseed oil & $\begin{array}{l}\text { Co-Mo/Mesoporous } \\
\mathrm{Al}_{2} \mathrm{O}_{3}\end{array}$ & $523-623$ & WHSV $=1.5 \mathrm{~h}^{-1}$ & $7-70$ & $\begin{array}{l}\text { High temperature and low } \\
\text { pressure give rise to the } \\
\text { increase in HDC }\end{array}$ & {$[61]$} \\
\hline 4 & $\begin{array}{l}\text { Bench-scale } \\
\text { trickle- bed }\end{array}$ & $\begin{array}{l}\text { Refine and } \\
\text { acidic } \\
\text { vegetable oil }\end{array}$ & $\begin{array}{l}\mathrm{NiMo} / \gamma-\mathrm{Al}_{2} \mathrm{O}_{3}, \mathrm{Co}- \\
\mathrm{Mo} / \gamma-\mathrm{Al}_{2} \mathrm{O}_{3}\end{array}$ & $\begin{array}{l}583.15- \\
623.15\end{array}$ & WHSV $=1.4 \mathrm{~h}^{-1}$ & 33 & $\begin{array}{l}52 \pm 3 \% \text { hydrocarbon } \\
\text { conversion }\end{array}$ & [62] \\
\hline 5 & Fixed bed & Rapseed oil & $\begin{array}{l}\mathrm{Mo} / \mathrm{Al}_{2} \mathrm{O}_{3} \\
\mathrm{NiMo} / \mathrm{Al}_{2} \mathrm{O}_{3} \\
\text { sulfided } \mathrm{Ni} / \mathrm{Al} 2 \mathrm{O} 3\end{array}$ & 583 & WHSV $=2 \mathrm{~h}^{-1}$ & 35 & $\begin{array}{l}\mathrm{NiMo} / \mathrm{A} 12 \mathrm{O} 3 \text { produced } \\
\mathrm{HDC}, \mathrm{HDO} \text { hydrocarbon, } \\
\mathrm{Ni} / \mathrm{Al} 2 \mathrm{O} 3 \text { produced } \mathrm{DC} \text {, } \\
\mathrm{Mo} \mathrm{Al}_{2} \mathrm{O}_{3} \quad \text { produce } \\
\text { absolutely } \mathrm{HDO} \text { product }\end{array}$ & [63] \\
\hline 6 & $\begin{array}{l}\text { Fixed-bed flow } \\
\text { reaction system }\end{array}$ & vegetable oil & $\mathrm{Ni}-\mathrm{Mo} / \mathrm{Sio}_{2}$ orAl ${ }_{2} \mathrm{O}_{3}$ & 623 & LHSV $=7.6 \mathrm{~h}^{-1}$ & $\begin{array}{l}\mathrm{H}_{2} / \mathrm{Oil}=800 \mathrm{~m} \\
\mathrm{~L} / \mathrm{Ml},\end{array}$ & $\begin{array}{l}\mathrm{n}-\mathrm{C}_{18} \mathrm{H}_{38}, \quad \mathrm{n}-\mathrm{C}_{17} \mathrm{H}_{36}, \quad \mathrm{n}- \\
\mathrm{C}_{16} \mathrm{H}_{34} \text {, and } \\
\mathrm{n}-\mathrm{C}_{15} \mathrm{H}_{32} \text { hydrocarbons }\end{array}$ & [64] \\
\hline 7 & Laboratory flow & Rapseed oil & $\mathrm{NiMo} / \mathrm{Al}_{2} \mathrm{O}_{3}$ & 583.15 & WHSV $=1 \mathrm{~h}-{ }^{1}$ & 70 and 150 & Hydrocarbon yield & [65] \\
\hline 8 & $\begin{array}{l}\text { High-pressure } \\
\text { batch }\end{array}$ & Soybean oil & $\begin{array}{l}\mathrm{Ni}-\mathrm{Mo} / \gamma-\mathrm{Al}_{2} \mathrm{O}_{3} \\
\mathrm{pd} / \gamma-\mathrm{Al}_{2} \mathrm{O}_{3}, \mathrm{Ni}-/ \mathrm{Sio}_{2-} \\
\mathrm{Al}_{2} \mathrm{O}_{3}, \mathrm{Ru} / \gamma-\mathrm{Al}_{2} \mathrm{O}\end{array}$ & 673 & $\begin{array}{l}\text { Catalyst/oil } \\
\text { weight ratio of } \\
6.04\end{array}$ & 92 & $\begin{array}{l}\text { NiMo and CoMo good for } \\
\text { the pathway }\end{array}$ & [66] \\
\hline 9 & Fixed bed & $\begin{array}{l}\text { Sunflower } \\
\text { oil }\end{array}$ & $\begin{array}{l}\text { Sulfided } \\
\text { commercial } \\
\text { hydrocraking } \\
\text { catalyst }\end{array}$ & $633-693$ & WHSV $=1.5 \mathrm{~h}^{-1}$ & 180 & Low heating properties & [67] \\
\hline 10 & Batch reactor & Rapseed oil & $\begin{array}{l}\mathrm{Pt} / \text { zeolite }(\mathrm{HY}-\mathrm{H}- \\
\mathrm{ZSM}-5) \text { sulphide Ni- } \\
\mathrm{Mo} / \mathrm{Al}_{2} \mathrm{O}_{3}\end{array}$ & $573-673$ & LHSV $=3 \mathrm{~h}^{-1}$ & $50-110$ & $\begin{array}{l}\text { Highest amount } \\
\text { hydrocarbon obtained. }\end{array}$ & [68] \\
\hline 11 & Fixed bed & Rapseed oil & Co-Mo/MCM-41 & $573-593$ & WHSV $=1-4 \mathrm{~h}^{-1}$ & $20-110$ & $\begin{array}{l}\text { Lower conversion than } \\
\mathrm{CoMo} / \mathrm{Al}_{2} \mathrm{O}_{3} \text {, }\end{array}$ & [69] \\
\hline 12 & $\begin{array}{ll}\text { Quartz } & \text { tubular } \\
\text { reactor } & \end{array}$ & $\begin{array}{l}\text { Oleic acid } \\
\text { and canola } \\
\text { oil }\end{array}$ & $\begin{array}{l}\text { Mo,W,V,nitrides/ } \\
\mathrm{Al}_{2} \mathrm{O}_{3}\end{array}$ & $653-683$ & LHSV $=0.45 \mathrm{~h}^{-1}$ & 715 & $\begin{array}{l}\text { Oxygen removal exceeded } \\
90 \%\end{array}$ & [70] \\
\hline 13 & $\begin{array}{l}\text { Small scale pilot } \\
\text { plant unit of } \\
\text { CPERI/CERTH }\end{array}$ & $\begin{array}{l}\text { Waste } \\
\text { cooking oil }\end{array}$ & $\begin{array}{l}\text { Commrecial } \\
\text { hydrocracking } \\
\text { catalyst }\end{array}$ & $603-671$ & $\begin{array}{l}\text { LHSVs(0.5,1.0, } \\
\text { and } 1.5) \mathrm{h}^{-1}\end{array}$ & 827 and965 & $\begin{array}{l}\text { Nitrogenand sulphur } \\
\text { removal above99\% oxygen } \\
\text { removal,less than } 90 \% \\
\text { oxygen was removed. }\end{array}$ & [71] \\
\hline
\end{tabular}


International Journal of Engineering Research and Technology. ISSN 0974-3154 Vol.13, No.3 (2020), pp. 500-519

(C) International Research Publication House. https://dx.doi.org/10.37624/IJERT/13.3.2020.500-519

\section{CATALYST SELECTION}

The choice of catalyst determines the yield and quality of the biofuel product; therefore, catalyst selection is a critical step for the production of green diesel. The purpose of any catalyst is to ensure the conversion of triglycerides to a high yield of hydrocarbon products [72]. Micro-physical properties and ionic composition of a catalyst have a great influence on the production of HDRD. The structural information of a catalyst can be studied using a transmission electron microscope (TEM) from single nanometric range to $500 \mathrm{~nm}$ range. The nano size, structural dimensions and active components of a catalyst provided effective surfaces for their catalytic effectiveness during hydrogenation processes. The total surface area of a catalyst can be obtained by Brunauer-Emmett-Teller (BET) using a nitrogen adsorption/desorption analyser, Morphological and structural studies of catalysts can be conducted by scanning electron microscope with energy dispersive X-ray detector (SEM-EDS), while thermal stability of the catalysts can be examining by a thermo-gravimetric analyser. Hydro-processing catalysts that are commonly used in literature are $\mathrm{Ni}$, $\mathrm{Co}$, and Mo as active metals which are usually supported by alumina or silica alumina [51]. Also, Co-Mo and Ni-Mo catalyst with alumina ( $\gamma$-Al2O3) have been widely used for hydrogenation, HDO, and hydrocarboxylation which is also a good desulphurisation (HDS) catalyst [73]. The activities of catalysts are to break the bonds and these are most likely to influence the route and the degree of $\mathrm{C}-\mathrm{C}$ and $\mathrm{C}-\mathrm{O}$ bond cleavage $[74,75]$. A variety of catalysts can be used for this process including $\mathrm{NiMo} / \mathrm{Al} 2 \mathrm{O} 3$ or $\mathrm{CoMo} / \mathrm{Al} 2 \mathrm{O} 3$ [75], $\mathrm{CoMo} / \mathrm{C}$ [76], CoMo/Si [74], depending upon the hydroprocessing route and reaction required.

Many researchers have investigated the right catalyst for the production of biodiesel and HDRD and discovered that the choice of catalyst selectivity for hydrocarbon conversion of triglycerides depends on the catalyst's activities and the nature of the catalyst. The hydrocarbon product expected during hydrodeoygenation will inform the choice of catalyst selection and will also depend on the reaction conditions i.e. temperature, pressure, liquid space hour velocity (LSHV) and $\mathrm{H} 2$ to oil (volume/volume) ratio [77]. Water vapor removal from HDRD during HDO requires selection of a catalyst that will stimulate the activity stability, which ultimately reduces the degree of the oxygenation [78]. Marker et al. [79] investigated the type of catalysts that can accommodate water and generate hydrogen [79]. Brady et al. [79] processed rapeseed oil, sewage sludge fish oil, corn oil, and canola oil soybean oils, etc. [79]. Herskowitz et al. [79] conducted studies for (C14-C18) n-paraffin with a low aromatic composition produced from animal fats and vegetable oil [79]. Myllyoja et al. $[80,81]$ produced biofuel with isomerization in diesel range (C15-C18) using different techniques. The elimination of liquid during HDO reaction is important because its presence in the reaction mixture can cause catalyst deactivation especially when batch reactors are used.

Studies from the literature have shown that sulphided Co$\mathrm{Mo} / \gamma-\mathrm{Al} 2 \mathrm{O} 3$ and $\mathrm{Ni}-\mathrm{Mo} / \gamma-\mathrm{Al} 2 \mathrm{O} 3$ are the active catalysts for hydrodesulphurization (HDS) that are mostly used for sulphur removal in HDO [82]. Several catalysts can be used during hydroprocessing to obtain green diesel products from vegetable oil or animal fats, depending upon the choice of production pathways. Hydrocracking and hydrogenation are another important route to consider to obtain optimal hydrocarbon in green diesel range by hydro-processing technology. A combined sulfided $\mathrm{Ni}-\mathrm{Mo} / \mathrm{Al} 2 \mathrm{O} 3$ catalyst offers the best yield for diesel range of $\mathrm{C} 15-\mathrm{C} 18$ product from a mixture of waste soya oil and gas-oil due to minimal cracking, while a sulphided $\mathrm{Ni}-\mathrm{W} / \mathrm{SiO} 2-\mathrm{A} 12 \mathrm{O} 3$ catalyst gives considerable jet range product due to catalytic cracking [7]. Zhang et al. reported that several routes have been practiced to produce biofuels from vegetable oil and animal fats [83]. HDO and hydroisomerization-hydrocracking routes are employed to produce long-chain paraffin and to improve the cold flow properties respectively in a reactor. Sinha et al. [84] carried out research on bio-jet fuel production using jatropha oil as feedstock by a single-step route using hierarchical ZSM-5supported with NiMo or NiW catalysts. The selection of route and the type of catalyst used will determine the cost and feasibility of obtaining optimal yield of green diesel. There is a research gap regarding the preparation of the type of feedstock, and the type of catalyst and the type of reactor that are most suitable in order to obtain quality green diesel. How to identify the right type of catalyst/support structure with the capacity of converting UCO into HDRD is a critical step.

Kim et al. [18] concluded that the DO of triglycerides via hydrotreatment should occur in a separate reactor through hydrocracking. Having studied various parameters in the catalytic hydro-processing of palm oil to optimize the production of bio-jet fuel, the authors affirm that the $\mathrm{CO}$ generated during DO can result in corrosion, which can lead to deactivation of the catalyst during DO of triglyceride via hydrotreatment process. Harnos et al. [85] tested Pd/activated C, Pd/Al2O3, Ni/Al2O3, and Ni-Mo/Al2O3 catalysts with a temperature at $613.15 \mathrm{~K}$ and pressure at 21 bars and found that the major product distribution was $\mathrm{C} 17, \mathrm{C} 18$, and small alkanes.

Gusmao et al. [53] obtained maximum conversion by the HDO route using vegetable oil, $\mathrm{Ni} / \mathrm{SiO} 2$ and $\mathrm{Ni}-\mathrm{Mo} / \gamma-\mathrm{Al} 2 \mathrm{O} 3$ catalysts $623 \mathrm{~K}$ to $673 \mathrm{~K}$ temperature at 10 bars to 200 bars pressure for $2 \mathrm{~h}$ in a batch reactor [53].

Veriansayah et al. [86] used soybean oil for HDO in the presence of many sulphided catalysts such as $\mathrm{Ni} / \mathrm{SiO} 2-\mathrm{Al} 2 \mathrm{O} 3$, $\mathrm{Ni}-\mathrm{Mo} / \gamma-\mathrm{Al} 2 \mathrm{O} 3, \mathrm{Pd} / \gamma-\mathrm{Al} 2 \mathrm{O} 3, \mathrm{Ru} / \gamma-\mathrm{Al} 2 \mathrm{O} 3$ and $\mathrm{Pt} / \gamma-\mathrm{Al} 2 \mathrm{O} 3$. Process parameters of 92 bars and $673 \mathrm{~K}$ and an oil/weight ratio of 6.044 was used in the batch reactor. The following results were obtained from higher to lower catalysts: NiMo > $\mathrm{Pd}>$ Castor $>\mathrm{Ni}>\mathrm{Pt}>\mathrm{Ru}$, at the catalyst/oil weight ratio of 0.044 and $\mathrm{Ni}>\mathrm{NiMo}>\mathrm{Pd}>\mathrm{CoMo}$ at the catalyst/oil weight ratio of 0.088 [86].

Aslam et al. [87] reported newly introduced catalysts for hydroprocessing of Jatropha curcas oil and FFA Mesua ferrea L. and Jatropha curcas oil, known as Musa balbisiana Colla underground stem (MBCUS), a nanomaterial, and a biomassbased thermal power plant fly ash (BBTPFS). The production pathway showed that the desired hydrocarbons in C18-C19 occurred through hydrocracking, decarboxylation, hydrolysis, and thermocatalytic cracking. When they compared the conversion rates they discovered that catalyst acidity and 
heteroatom removal also showed BBTPFS to be a better choice than MBCUS. Knoshaug et al. [88] investigated the production of green diesel using biomass from the green alga Scenedesmus acutus to produce succinic acid; the lipids produced in this reaction as a by-product, with $83 \%$ yield, were deoxygenized through HDO and hydroisomerization to produce green diesel. Toth et al. [89] produced hydrocarbon fuel in the diesel range by the HDO of mixture of gas oil and sunflower oil. He found out that products with less aromatic and fewer sulphur contents were produced at 80 bars and $634.15 \mathrm{~K}$ pressure and temperature respectively with LHSV of $1.0 \mathrm{~h}-1$ and hydrogen/feedstock ratio $=600 \mathrm{Nm} 3 / \mathrm{m} 3$ on varied vegetable oil contents ( $0 \mathrm{wt} \%$ to $15 \mathrm{wt} \%$ ). The $15 \mathrm{wt} \%$ vegetable oil gave the highest $\mathrm{CN}$. Similarly, the isomerization properties of the products were enhanced at low temperatures [89]. Huber et al. [90-92] investigated HDO by co-processing of sunflower oil and heavy vacuum oil (HVO) mixtures. Nickel molybdenum / alumina was used, with pressure at 50 bars and temperature at $573 \mathrm{~K}$ to $723 \mathrm{~K}$ in a tubular reactor. They observed that the selectivity for HDO products increased under certain reaction conditions. Another co-processing experiment was carried out by Bezergianni et al. [93]. They conducted HDO by using heavy atmospheric gas oil (HAGO) and WCO. The active catalysts like $\mathrm{Co}-\mathrm{Mo} / \mathrm{Al} 2 \mathrm{O} 3$ and $\mathrm{Ni}-\mathrm{Mo} / \mathrm{Al} 2 \mathrm{O} 3$ were used at 56 bars pressure and temperatures of $603 \mathrm{~K}, 623$ $\mathrm{K}$, and $643 \mathrm{~K}$ in a fixed bed continuous flow reactor. It was found that Ni-Mo catalysts for HDO are the best under suitable reaction conditions [94]. The research works on HDO were carried out using model compounds to develop certain approaches to understand the kinetics of the single-step reactions in a reactor [95]. The model compounds such as decanoic acid [96], oleic acid [87, 97, 98], palmitic acid [79], stearic acid [99], and linoleic acid [100] were all tested for HDO. The detailed mechanism study of model compounds helps researchers to understand their action kinetics. Snare et al. [101] used oleic acid, linoleic acid (unsaturated fatty acid) and the monounsaturated fatty acid ester, methyl oleate as the model compounds of vegetable oil for HDO using Pd/C $5 \mathrm{wt} \%$ catalyst, 15 bars and 27 bars and $573 \mathrm{~K}$ to $633 \mathrm{~K}$ for $6 \mathrm{~h}$ in a semi-batch reactor. They observed a high selectivity and high yield towards the hydrocarbon conversion. The catalyst properties for upgrading vegetable oils to obtain quality and optimal yield using the hydroprocessing technique must possess the following factors: zero coke formation, high resistance to chemical attack, sustainability in commercial processes, resistance to water, high DO activity [102]. In order to make the resources of the production chain completely green, biomass-based thermal power plants fly ash (BBTPPFS) and calcium oxide $(\mathrm{CaO})$ need to be aggressively explored.

\section{PRODUCTION TECHNIQUES AND PARAMETERS}

The technology for producing fossil-based fuel has been in operation in refineries for many years. The same catalysts, reactor types and the distillation facilities used for the production of petroleum-based fuel can be used for the hydroprocessing of biologically derived feedstocks to obtain high-quality hydrocarbon which means that large savings are possible since the same refinery facilities are used. The same production technology used in conventional refinery for desulfurization and fractional distillation can be adapted for hydroprocessing of vegetable oils and animal fats to produce green diesel or HDRD. Vegetable oils can be co-processed with the diesel oil feed or by building a stand-alone hydrotreatment unit for producing HDRD. However, coprocessing involves shutting down the reactor when necessary changes are required between catalyst bed, operating condition and mode of operation. Since the process gives off heat, and large amounts of hydrogen are required in hydroprocessing of vegetable oils feed, a co-feed of above $15 \%$ may pose serious challenges. Hydroprocessing of renewable feedstocks using stand-alone units can be optimized and controlled to achieve higher yields of HDRD production. Stand-alone units can be constructed as an attachment to existing refineries and the existing hydrogen in the refinery can be streamlined as recycled gas. Neat HDRD or blending of HDRD with conventional diesel is possible on-site before distribution, hence the blend percentage can be determined based on market conditions with no significant changes in operating conditions. The main drawback of a stand-alone production facility is the initial high capital costs for the building of infrastructure.

The choice of feedstock can greatly influence the production of green diesel, a second-generation biofuel known as "renewable diesel", also known as hydrogenation derived renewable diesel (HDRD). The feedstocks used for the production of HDRD are plant-derived edible oils such as, rapeseed, soybeans, and palm [103-106], and non-edible oils such as Jatropha and algal oils and UCO products which are now considered the most popular feedstock [105, 107]. Many researchers have confirmed UCO as being the most viable, cost-effective and available feedstock in recent years. Researchers are still investigating the most suitable technology for the production of green diesel that is cost-effective and CI engine compatible. Production of green diesel from biomass can be accomplished through four technologies: (i) Hydro-processing, which aims to convert the triglycerides of the feedstock oils and fats into saturated hydrocarbon products through catalytic processing with hydrogen; (ii) Catalytic upgrading of sugars, starches, and alcohols, which involves liquid phase technologies such as aqueous phase reforming (APR); and (iii) Thermal conversion (pyrolysis) and upgrading of bio-oil which is then refined into green diesel; and (iv) Biomass to liquid (BTL) thermochemical processes, which involve the high-temperature gasification of the biomass for the production of syngas which is rich in $\mathrm{H}_{2}$ and CO. The green diesel produced by the Fischer-Tropsch method is referred to as FT green diesel [108, 109]. Hydroprocessing is mainly comprised of two steps viz hydrocracking and hydrotreating [110].

Kumar et al. produced green diesel by hydroprocessing and reported that about $85 \%$ (by vol.) biofuel was produced while $10 \%$ were gases which escaped in the form of noncondensable gases and $4 \%$ to $5 \%$ collected at the base of the flask in the form of water [111]. Green diesel is a mixture of straight-chain and branched saturated hydrocarbons which contain carbon atoms of $\mathrm{C} 15$ to $\mathrm{C} 18$. This composition is the same as conventional petroleum diesel which makes green diesel compatible with $\mathrm{CI}$ engines without engine modifications [112, 113]. In this context, green diesel is reliable and is emerging as the most promising biofuel because 
it has better fuel properties compared to biodiesel and petroleum diesel. Green diesel has been found to possess a high $\mathrm{CN}$, oxidation stability, cold flow properties, and cloud point compared to biodiesel and petroleum diesel [114]. The energy density of green diesel is greater compared to petroleum diesel and biodiesel. Fahmi et al. reported that the $\mathrm{CN}$ of green diesel is between 80 to 99 which is much higher than conventional diesel standards [115]. The density and the net heating value of green diesel are in the range of $0.77 \mathrm{~g} / \mathrm{ml}$ to $0.83 \mathrm{~g} / \mathrm{ml}$ and 42
$\mathrm{MJ} / \mathrm{kg}$ to $44 \mathrm{MJ} / \mathrm{kg}$ respectively, which also meets the biodiesel and petrodiesel standards [116]. The regulatory bodies have come up with a standard to control the quality of HDRD. Table 7 shows the properties of biofuels according to the standards American Society for Testing and Materials, ASTM D975, EN 15940:2016, EN 590:2013 in Europe, Canadian General Standards Board (CGSB) in Canada, and Neste Renewable Diesel.

Table VII. Typical properties of pure Neste Renewable Diesel and how it relates to EN 15940, EN 590 and ASTM D975 Standards

\begin{tabular}{|c|c|c|c|c|c|c|}
\hline Properties & unit & $\begin{array}{l}\text { ASTM } \\
\text { D975 }\end{array}$ & $\begin{array}{l}\text { EN } \\
\text { 15940:2016 } \\
\text { Class A }\end{array}$ & $\begin{array}{l}\text { EN } \\
590: 2013\end{array}$ & $\begin{array}{l}\text { Neste } \\
\text { HDRD }\end{array}$ & $\begin{array}{l}\text { HDRD } \\
\text { CGSB }\end{array}$ \\
\hline & & Standard & & Standard & & \\
\hline Density at $+15^{\circ} \mathrm{C}$ & $\mathrm{Kg} / \mathrm{m}^{3}$ & - & $765-800$ & $820-845$ & $770-790$ & - \\
\hline Ash & $\%(\mathrm{~m} / \mathrm{m})$ & 0.01 & $\leq 0.010$ & $\leq 0.010$ & $<0.001$ & 0.01 \\
\hline $\begin{array}{l}\text { Carbon residue on } \\
10 \% \text { distillation }\end{array}$ & $\%(\mathrm{~m} / \mathrm{m})$ & 0.35 & $\leq 0.30$ & $\leq 0.30$ & $<0.10$ & 0.15 \\
\hline Cetane Number & & 40 & $\geq 70$ & $\geq 51.0$ & $>70$ & 40 \\
\hline $\begin{array}{l}\text { Appearance at } \\
+25^{\circ} \mathrm{C}\end{array}$ & & - & - & - & Clear & - \\
\hline Water & $\mathrm{Mg} / \mathrm{kg}$ & - & $\leq 200$ & $\leq 200$ & $<200$ & - \\
\hline Flash point & ${ }^{0} \mathrm{C}$ & 52 & $>55$ & $>55$ & $>61$ & 40 \\
\hline FAME-content & $\%(\mathrm{~V} / \mathrm{V})$ & - & $\leq 7.0$ & $\leq 7.0$ & 0 & - \\
\hline Water and sediment & $\%(\mathrm{~V} / \mathrm{V})$ & 0.05 & - & - & $\leq 0.02$ & 0.05 \\
\hline Polyaromatics & $\%(\mathrm{~m} / \mathrm{m})$ & - & - & $\leq 8.0$ & $<0.1$ & - \\
\hline Copper corrosion & - & - & Class 1 & Class 1 & Class 1 & - \\
\hline $\begin{array}{l}\text { Lubricity HFRR at } \\
60^{\circ} \mathrm{C}\end{array}$ & $\mu \mathrm{m}$ & - & $\leq 460$ & $\leq 460$ & $\begin{array}{l}\leq 460 \\
650\end{array}$ & - \\
\hline Conductivity & $\mathrm{Ps} / \mathrm{m}$ & - & - & - & $\geq 50$ & - \\
\hline Final boiling point & ${ }^{0} \mathrm{C}$ & - & - & - & $<330$ & - \\
\hline $\begin{array}{l}\text { Distillation } \\
95 \%(\mathrm{~V} / \mathrm{V}) \\
90 \%(\mathrm{~V} / \mathrm{V})\end{array}$ & $\begin{array}{l}{ }^{0} \mathrm{C} \\
{ }^{0} \mathrm{C}\end{array}$ & - & $\leq 360$ & $\leq 360$ & $\begin{array}{l}<320 \\
282-338\end{array}$ & - \\
\hline Total contamination & $\mathrm{Mg} / \mathrm{Kg}$ & - & $\leq 24$ & $\leq 24$ & $<10$ & - \\
\hline Oxidation stability & $\mathrm{M} / \mathrm{g}^{3}$ & - & $\leq 25, \geq 20 * *$ & $\begin{array}{l}\leq 25, \geq \\
20 * *\end{array}$ & $<25$ & - \\
\hline Sulphur & $\mathrm{Mg} / \mathrm{Kg}$ & 15 & $\leq 5.0$ & $\leq 10.0$ & $<5.0$ & 1.5 \\
\hline Final boiling point & ${ }^{0} \mathrm{C}$ & - & & & $<330$ & - \\
\hline Viscosity at $+40^{\circ} \mathrm{C}$ & $\mathrm{mm}^{2} / \mathrm{s}$ & $1.9-4.1$ & $2.000-4.500$ & $\begin{array}{l}2.000- \\
4.500 \\
\geq 1.200 \\
\end{array}$ & $\begin{array}{l}2.000--- \\
4.000\end{array}$ & $1.7-4.1$ \\
\hline Antistatic additive & & - & & & added & - \\
\hline $\begin{array}{l}\text { Cloud point and } \\
\text { CFPP } * * * *\end{array}$ & ${ }^{0} \mathrm{C}$ & - & $\begin{array}{ll}\text { As } & \text { in } \\
\text { EN590 } & \end{array}$ & $\begin{array}{l}\text { Down to - } \\
34\end{array}$ & $\begin{array}{l}\text { As needed } \\
-5----34\end{array}$ & - \\
\hline Total aromatic & $\%(\mathrm{~m} / \mathrm{m})$ & - & $\leq 1.1$ & $<1.0$ & $<1.0$ & - \\
\hline Cetane index & - & 40 & - & - & - & - \\
\hline Acid number & $\mathrm{MgKOH} / \mathrm{g}$ & & & & & 0.10 \\
\hline
\end{tabular}

Source: Eco Resources consultants for Natural Resources Canada. 


\section{Process Parameter}

The optimum operating parameter is an important consideration in the hydroprocessing of green diesel. The parameters to be evaluated are reaction temperature, pressure, and low hourly space velocity (LHSV). The LHSV is a key parameter to control catalyst effectiveness and life expectancy, $\mathrm{H}_{2}$ /oil ratio, catalyst, catalyst amount, type of feed, feed rate, reactor type and type of solvent. Critical reviews of reactors for hydroprocessing catalysts have been conducted by many researchers [117], reporting the following: batch reactor or fixed-bed microreactors can successfully screen new catalysts either in particle or in powdered form which makes it possible to compare a catalyst in line with their rate of inert reaction. The reaction conditions in the reactor during hydroprocessing activities has a significant influence on the yield and the quality of hydrocarbon products. Heteroatoms are atoms like sulfur, nitrogen, and oxygen which are present in the bio-based and fossil-based feedstock. Bio-based feedstock comprises oxygen with no sulfur and nitrogen. The presence of oxygen is a threat to the green diesel product because it increases acidic and corrosion attack and reduces oxidation stability [118]. UCO has been used by many researchers and is considered as the best feedstock. The effect of the process parameters affects the composition of the green diesel products [119].

\section{HYDROGEN}

The applications of hydrogen in the production cycle of green diesel is the focus of this section. Hydrogen plays a significant role in hydroprocessing technology. Hydrogen carries the energy and can be produced from fossil fuels, nuclear, solar, wind, biomass, hydro, geothermal and urban waste resources [7]. Electrical power is another source which can produce hydrogen on the scale required to sustain the energy sector. The availability of various resources to produce hydrogen makes hydrogen a promising energy resource. Hydrogen is one of the most abundant elements in the world. Hydrogen has tendencies to combine with other chemical elements to form substances like hydrocarbon, or alcohol, or water. Municipal solid waste product is the cheapest, available and sustainable resource for production of hydrogen using the electrolysis method. These resources can be harnessed to produce hydrogen at a cheap price. The production of hydrogen per year is estimated to be 55 million tons with $6 \%$ increase in consumption per annum However, currently, almost $50 \%$ of the demand for hydrogen is generated from steam reforming of natural gas, $30 \%$ from naphtha from refineries, $18 \%$ from coal gasification, $3.9 \%$ from electrolysis, and $0.1 \%$ from other sources [120]. Technological processes to produce hydrogen include electrolysis, thermal energy, and photolysis. Hydrogen is produced by the steam reforming (SR) of natural gas which leads to massive emissions of pollutants [121, 122]. The effect of these emissions in the environment renders production of hydrogen unsustainable. High efficiency can be obtained by electrolytic and plasma processes but the high consumption of energy is a challenge [123]. Coal gasification is another potential source of hydrogen production because of the abundant deposits globally and a cheap price [123]. However, the production of hydrogen from this source is not sustainable because the energy required for confiscation of $\mathrm{CO}_{2}$ will increase the consumption rate of coal. Hydrogen production from renewable energy resources like geothermal, solar derived, nuclear, and wind energy are sustainable, but the challenge is that the unit cost of electricity will increase the cost of production.

Sourcing hydrogen from solid waste for HDRD application in South Africa offers many benefits like waste management and income generation (waste to wealth). South Africa generated 10.8 million tons of waste per annum, which amounted to 295890 tons per day, in 2011 [124]. However, $70 \%$ of this waste is biodegradable from which 394520 tons/annum of hydrogen yield can be obtained. Biomass is available but it cannot meet the required supply of hydrogen because the growing of crops as a source of fuel will attract significant resistance.

Hydrogen can be produced via the water pyrolysis method. Temperatures of approximately $2000{ }^{\circ} \mathrm{C}$ are required for direct thermal water splitting that produces a mixture of hydrogen and oxygen [125]. A few thermal chemical cycles have been identified; chemical cycles can be used to lower temperatures to produce hydrogen and oxygen in separate steps, for example sulphuric acid $\left(\mathrm{H}_{2} \mathrm{SO}_{4}\right)$ at $850{ }^{\circ} \mathrm{C}$ and hydrogen iodide (HI) at $450{ }^{\circ} \mathrm{C}$ [126]. The design of a fission reactor must consider the mechanical properties of the materials that can offer adequate heat to enhance stability under operating conditions of $\mathrm{HI}$ and $\mathrm{H}_{2} \mathrm{SO}_{4}$. But the operating cost of nuclear and waste handling makes this source unsustainable. Production of hydrogen can be achieved by photo-biological [127] and photo electrochemical processes [128, 129]. This is a technology that uses direct irradiation and water resources for the production of hydrogen and it has the tendency to increase the efficiency of the solar-to-hydrogen pathway [130]. This technology allows the use of seawater as feedstock, and open land space is used to collect sunlight energy, thus it is sustainable and cost-effective. These technologies are under investigation for future applications.

These sources for the production of hydrogen will enhance the HDRD production value chain so that it is completely green. 
International Journal of Engineering Research and Technology. ISSN 0974-3154 Vol.13, No.3 (2020), pp. 500-519

(C) International Research Publication House. https://dx.doi.org/10.37624/IJERT/13.3.2020.500-519

Table VIII. Advantages and disadvantages of different hydrogen(H2) production technology [131]

\begin{tabular}{|c|c|c|c|}
\hline Technology & Disadvantages & Advantages & $\begin{array}{l}\text { Efficiency } \\
\quad(\%)\end{array}$ \\
\hline Biomass pyrolysis & $\begin{array}{l}\text { Feedstock contamination, seasonal } \\
\text { availability lead to varring content }\end{array}$ & Abundant and cheap feedstock, neutral $\mathrm{CO}_{2}$ & $35-50$ \\
\hline Steam reform (SR) & Use fossil fuels, $\mathrm{CO}_{2}$ emmission & $\begin{array}{l}\text { Existing facilities reduces cost, developed } \\
\text { technology }\end{array}$ & $74-85$ \\
\hline Electrolysis & $\begin{array}{l}\text { Overall efficiency is low, capital cost is } \\
\text { high }\end{array}$ & $\begin{array}{l}\text { Use of existing technology, good technology, } \\
\text { available and abundant technology, } \mathrm{O}_{2} \text { is the } \\
\text { only by-product, pollution free with } \\
\text { renewable sources }\end{array}$ & $40-60$ \\
\hline Thermolysis & $\begin{array}{l}\text { Corrosive problems, toxic element, high } \\
\text { cost }\end{array}$ & Abundant feedstocks, clean and sustainable. & $20-45$ \\
\hline Biomass-gasification & $\begin{array}{l}\text { Feedstock contamination, tar formation, } \\
\text { seasonal availability. }\end{array}$ & Abundant and cheap feedstocks, neutral $\mathrm{CO}_{2}$ & - \\
\hline Photo-electrolysis & $\begin{array}{l}\text { Conversion rate is low, sunlight requires, } \\
\text { poor effective photocatalyst materials }\end{array}$ & $\begin{array}{l}\text { Available feedstocks,pollution free, } \mathrm{O} 2 \text { is the } \\
\text { only by product. }\end{array}$ & 0.06 \\
\hline Partial oxidation (POX) & $\begin{array}{l}\text { Depend sole on petroleum product, } \mathrm{CO} 2 \\
\text { emission }\end{array}$ & $\begin{array}{l}\text { Make use of existing technology, proven } \\
\text { technology }\end{array}$ & $60-75$ \\
\hline
\end{tabular}

\section{A. Effect of Reaction Temperature}

The effect of temperature during hydrotreating of feedstock has a great impact both on the biofuel yield and the quality of the expected fuel. Simacek et al. [132] obtained the conversion of rapeseed oil between the temperatures of $310{ }^{\circ} \mathrm{C}$ and $360{ }^{\circ} \mathrm{C}$. Kubicka [133] and [134] obtained a fully converted biofuel yield within the range of $80 \mathrm{wt} \%$ to $90 \mathrm{wt} \%$. Kikhtyanin et al. [40] achieved full conversion of sunflower oil with optimal temperature range of $320{ }^{\circ} \mathrm{C}$ to $350{ }^{\circ} \mathrm{C}$ in the presence of $\mathrm{Pd} / \mathrm{SAPO}$ catalyst, while Hancsok et al. [52] used Pt/HZSM22/A12O3 catalyst at $350{ }^{\circ} \mathrm{C}$ to convert sunflower oil to biofuel.

Bezergianni et al. studied catalyst effectiveness over the temperature range prescribed by catalyst manufacturers, i.e. within the temperature range of $330{ }^{\circ} \mathrm{C}$ to $390{ }^{\circ} \mathrm{C}$, under constant LHSV (1hr-1) and a range pressure of 1200 psig to 2000 psig. The results showed that the hydrotreating catalysts exhibited the highest conversion $(\sim 83 \%)$ as well as the highest diesel selectivity.

Bezergianni et al. [87] investigated the hydrotreatment of UCO in terms of the rate of conversion, heteroatom removal, product yield, temperature variation, saturation of double bond, and selectivity. The scholars deduced that the higher the temperature the higher the product yield. Temperature plays a vital role in the elimination of oxygen content in order to increase the heating value of the biofuel; an increase in temperature and pressure reduces the concentration of oxygen significantly, but during hydroprocessing, high temperatures cause low oil yield and high hydrogen consumption. There is a need to further investigate optimization of operating conditions in order to find out the relationship between temperature, hydrogen consumption, and oil yield. A temperatures range of $300{ }^{\circ} \mathrm{C}$ to $400{ }^{\circ} \mathrm{C}$ and a hydrogen pressure range between 6 $\mathrm{MPa}$ to $20 \mathrm{MPa}$ is commonly used for hydrotreating processes [135].
Biofuel production via hydroprocessing of UCO was studied by Bezergianni et al. They discovered that temperature is the most significant operating parameter which enhances catalyst performance and the life span of catalysts. Their study utilised temperatures of $330{ }^{\circ} \mathrm{C}, 350{ }^{\circ} \mathrm{C}, 370{ }^{\circ} \mathrm{C} 385$ and $398^{\circ} \mathrm{C}$ [136].

\section{B. Effect of Hydrogen Pressure}

The effect of hydrogen on the production of biofuel is the focus of this section. Hydrogen has a great impact during hydroprocessing of biofuel. In the reaction mechanism, hydrogen pressure strongly affects hydrotreatment, isomerization, hydrogenation and cracking processes. Hydrogen pressure was varied between 8.27 $\mathrm{MPa}$ and 9.65 $\mathrm{MPa}$ to investigate the effect during the hydrotreating of UCO [137]. It was reported that higher hydrogen pressure of 9.65 $\mathrm{MPa}$ gave a higher diesel-like yield of $71.36 \%$, oxygen removal efficiency of $94.25 \%, 4.03 \%$ and $5.16 \%$, and gasoline-like fuel yield was obtained at $8.29 \mathrm{MPa}$ and 9.65 $\mathrm{MPa}$ pressure respectively. This implies that higher hydrogen pressure gives lower yield while higher hydrogen pressure gives higher yield in diesel-like fuel, consequently, an increase in the cost of hydrogen. Sotelo-Boyas et al. reported that a hydrogen pressure of $8 \mathrm{MPa}$ to10 $\mathrm{MPa}$ is sufficient for liquid yield. Their study investigated hydrogen pressure and the catalyst and their effect on product yield [68].

Sunflower and gas oil blends over $\mathrm{NiMo} / \mathrm{Al}_{2} \mathrm{O}_{3}$ catalyst with 0 $\mathrm{wt} \%, 15 \mathrm{wt} \%$ or $30 \mathrm{wt} \%$ zeolite beta was co-hydro processed [138]. The authors found that the increase in hydrogen pressure from 30 bar to 60 bar for all the catalysts offered a good conversion. It was observed that the NiMo-30BEA catalyst was more active, and at 30 bar hydrogen pressure, $93 \%$ yield was obtained [138]. 
High hydrogen pressure inhibits liquid to a gaseous product, high hydrogen pressure does not support isomerization, and as higher hydrogen pressure consumption increases energy costs.

\section{Effect of liquid hourly space velocity}

Liquid hourly space velocity (LHSV) is the ratio of the mass feed rate of liquid $(\mathrm{g} / \mathrm{h})$ over the catalyst mass $(\mathrm{g})$ and is expressed h- $^{1}$ [139]. Mathematically, space velocity can be expressed as:

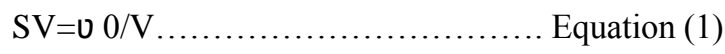

Where $v 0$ represents the volumetric flow rate of the reactants entering the reactor and $\mathrm{V}$ is the volume of the reactor itself.

This expression is the reciprocal of the definition for the reactor space-time, $\tau$ (i.e. $\mathrm{SV}=1 / \tau$ ). However, space-time is measured at the conditions of the reactor entrance while the space velocity is often measured at a set of standard conditions, so the reported space velocity may be different from the reciprocal of the measured space-time.

Bezergianni et al. varied LHSV of $0.5 \mathrm{~h}-1,1.0 \mathrm{~h}-1,1.5 \mathrm{~h}-1$ on the liquid product formed from hydrotreating of UCO over NiMo catalyst. The authors obtained a maximum conversion of $83.08 \%$ with an LHSV of $1.0 \mathrm{~h}-1$. The increase in LHSV to $1.5 \mathrm{~h}-1$ caused an increase in diesel yield to $97.46 \%$; a higher amount of diesel-like fuel was formed while sulfur and nitrogen present were removed with an increase in LHSV [137]. Bezergianni et al. obtained the same results during the hydrocracking of used cooking oil [140]. Hydro-processing of jatropha oil and the effect of LHSV on product yield was studied; it was reported that product yield decreased up to $6 \mathrm{~h}-1$ at $300{ }^{\circ} \mathrm{C}$, and increased slightly at $8 \mathrm{~h}-1$ due to change in the reaction pathways [141]. Hourly space velocity supports the removal of nitrogen and sulfur removal but reduces oxygen removal.

High hourly space velocity results in the formation of wax. An increase in hourly space velocity increases the choice of diesel selectivity.

\section{CONCLUSION}

The search for alternative sustainable renewable energy has influenced researchers to develop solutions to the environmental crises and global demand for fuel. Green diesel has received significant attention in the modern economy because HDRD offers higher stability, higher heating value, and emission of harmless pollutants. The use of non-edible oil such as UCO is more viable as it reduces the production cost and has the potential to settle the concerns related to the edible oil market. This critical review has identified UCO as a potential feedstock for hydroprocessing of HDRD. The main conclusions are:

- Used cooking oil has the potential to be a sustainable feedstock for HDRD; the production cost of green diesel will reduce when UCO is protected and harnessed as a source of feedstock.
- The right technology for HDRD production will promote the commercialization of green diesel.

- Catalyst selection has a great effect on hydrocarbon yield. BBTPPFS sourced from Eskom, characterized and prepared will offer optimal hydrocarbon yield. This choice of catalyst will make the value chain completely green. The effect of process parameters that influence the production of diesel range hydrocarbon has been studied via effect of temperature, H2/oil ratio, hydrogen pressure, and liquid hourly space velocity.

- As for the reaction temperature, a balance must be maintained in the selection of fuel range hydrocarbons and conversion rates of $\mathrm{UCO}$, regarding hydrogen pressure. High hydrogen pressure does not support isomerization, high hourly space velocity results in the formation of wax, and an increase in hourly space velocity increase the choice of selectivity. UCO has a low $\mathrm{pH}$ value which offers the best potential for hydrogenation.

- HDRD possesses superior fuel qualities such as CN, low pour point, and excellent oxidation stability which offers a great benefit for the CI engine and the environment.

- Used cooking oil sourced from domestic, restaurant and food industry can be harnessed for commercial production of HDRD.

\section{REFERENCES}

[1] Organisation for Economic Co-operation and Development, OECD Environmental Performance Reviews: Turkey 2019. 2019. Available: https://www.oecd.org/turkey/oecd-environmentalperformance-reviews-turkey-2019-9789264309753en.htm

[2] H. Mahmudul, F. Hagos, R. Mamat, A.A. Adam, W. Ishak, and R. Alenezi, "Production, characterization and performance of biodiesel as an alternative fuel in diesel engines-A review," Renewable Sustainable Energy Rev., vol. 72, pp. 497-509, 2017.

[3] Z. Yang, A. Kumar, and R.L. Huhnke, "Review of recent developments to improve storage and transportation stability of bio-oil," Renewable Sustainable Energy Rev., vol. 50, pp. 859-870, 2015.

[4] Energy Information Administration. EIA: world energy consumption to grow 56\% 2010-2040, CO2 up $46 \%$; use of liquid fuels in transportation up $38 \%$. July 2013.

Available: https://www.greencarcongress.com/2013/07/iea20130725.html

[5] S. Thaba, C. Mbohwa, and A. Pradhan, "Biofuel sector as a potential business opportunity for emerging cooperatives a case study of South African cooperatives," 2015. Available: http://www.iaeng.org/publication/WCECS2015/WCE CS2015_pp1011-1017.pdf

[6] M. Atapour, H.-R. Kariminia, and P. Moslehi 
Moslehabadi, Optimization of biodiesel production by alkali-catalyzed transesterification of used frying oil. Process Saf. Environ. Prot. Vol. 92, pp. 179-185, 2014.

[7] E. Onuh, F. Inambao, and O. Awogbemi, "Green diesel, renewable energy and waste cooking il: the potential for synergy," Int. J. Applied Eng. Res., vol. 13, no. 10, pp. 8714-8727, 2018.

[8] N.-O. Nylund, P. Aakko-Saksa, and K. Sipilä, Status and outlook for biofuels, other alternative fuels and new vehicles (no. VTT-TIED-2426). VTT, 2008. Available: http://www.ieabioenergy.com/wpcontent/uploads/2013/10/Status-and-outlook-forbiofuels-other-alternative-fuels-and-new-vehicles.pdf

[9] S. Lestari et al., "Catalytic deoxygenation of stearic acid in a continuous reactor over a mesoporous carbon-supported Pd catalyst," Energy Fuels, vol. 23, no. 8 , pp. 3842-3845, 2009.

[10] I. Simakova, O. Simakova, P. Mäki-Arvela, A. Simakov, M. Estrada, and D. Y. Murzin, "Deoxygenation of palmitic and stearic acid over supported Pd catalysts: effect of metal dispersion," Applied Catalysis A: General, vol. 355, no. 1-2, pp. 100-108, 2009.

[11] S. Oja, "NExBTL-next generation renewable diesel," Symposium New Biofuels, Berlin May 6-7 2008, Germany, 2008.

[12] A.C. Kokossis and A. Yang, "Future system challenges in the design of renewable bio-energy systems and the synthesis of sustainable biorefineries," in Design for Energy and the Environment, M.M. ElHalwagi and A.A. Linninger Eds, Boca Rotan: CRC Press, 2009, pp. 133-150.

[13] N. Lambert, "Study of hydrogenation derived renewable diesel as a renewable fuel option in North America, Final Report, Natural Resources Canada," Ontario, 2012.

[14] M. Naguran, "Sustainability issues and strategies of biofuel development in southeast Asia," in Sustainability Matters: Environmental and Climate Changes in the Asia-Pacific, L-H. Lye, V.R Savage, H.-W. Kua, L-M. Chou, and P-Y. Tan, Eds, Singapore: World Scientific, 2015, pp. 331-369.

[15] A. Milbrandt, C. Kinchin, and R. McCormick, "Feasibility of producing and using biomass-based diesel and jet fuel in the United States," National Renewable Energy Laboratory,. Golden, CO, 2013.

[16] J.-L. Wertz and O. Bédué, Lignocellulosic Biorefineries. Lausanne: EPFL Press, 2013.

[17] K.L. Kraemer, J. Dedrick, and S. Yamashiro, "Refining and extending the business model with information technology: Dell Computer Corporation," The Information Society, vol. 16, no. 1, pp. 5-21, 2000 .
[18] H. Suopajärvi and T. Fabritius, "Towards more sustainable ironmaking - an analysis of energy wood availability in Finland and the economics of charcoal production," Sustainability, vol. 5, no. 3, pp. 11881207, 2013.

[19] S.K. Hoekman, "Biofuels in the US-challenges and opportunities," Renewable Energy, vol. 34, no. 1, pp. 14-22, 2009.

[20] M. Specht, U. Zuberbuhler, and A. Bandi, "Why biofuels?-An introduction into the topic," RENEW1st European Summer School on Renewable Motor Fuels, Uwelt-Campus-Birkenfeld, 29th-31st August, 2005.

[21] B. Smith, H.C. Greenwell, and A. Whiting, "Catalytic upgrading of tri-glycerides and fatty acids to transport biofuels," Energy Environ. Sci., vol. 2, no. 3, pp. 262271, 2009.

[22] J. Calero et al., "An overview on glycerol-free processes for the production of renewable liquid biofuels, applicable in diesel engines," Renewable Sustainable Energy Rev., vol. 42, pp. 1437-1452, 2015.

[23] G. Abdulkareem-Alsultan, N. Asikin-Mijan, H.V. Lee, U. Rashid, A. Islam, and Y.H. Taufiq-Yap, "A review on thermal conversion of plant oil (edible and inedible) into green fuel using carbon-based nanocatalyst," Catalysts, vol. 9, no. 4, p. 350, 2019.

[24] M.R. Anuar and A.Z. Abdullah, "Challenges in biodiesel industry with regards to feedstock, environmental, social and sustainability issues: A critical review," Renewable Sustainable Energy Rev., vol 58, pp. 208-223, 2016.

[25] Z. Yaakob, I.S.B. Sukarman, B. Narayanan, S.R.S. Abdullah, and M. Ismail, "Utilization of palm empty fruit bunch for the production of biodiesel from Jatropha curcas oil," Bioresour. Technol., vol. 104, pp. 695-700, 2012.

[26] J. Qian, H. Shi, and Z. Yun, "Preparation of biodiesel from Jatropha curcas L. oil produced by two-phase solvent extraction," Bioresour. Technol., vol. 101, no. 18, pp. 7025-7031, 2010.

[27] S. Irwan, Z. Yaakob, M. S. Kumar, S. Primandari, and S. K. Kamarudin, "Biodiesel progress in Malaysia," Energy Sources, Part A, vol. 34, no. 23, pp. 21392146, 2012.

[28] H.A. Aziz, M.K. Aroua, R. Yusoff, N.A. Abas, Z. Idris, and H.A. Hassan, "Production of palm-based esteramine through heterogeneous catalysis," J. Surfactants Deterg., vol. 19, no. 1, pp. 11-18, 2016.

[29] A.E.-F. Abomohra, W. Jin, R. Tu, S.-F. Han, M. Eid, and H. Eladel, "Microalgal biomass production as a sustainable feedstock for biodiesel: current status and perspectives," Renewable Sustainable Energy Rev., vol. 64, pp. 596-606, 2016. 
International Journal of Engineering Research and Technology. ISSN 0974-3154 Vol.13, No.3 (2020), pp. 500-519

(C) International Research Publication House. https://dx.doi.org/10.37624/IJERT/13.3.2020.500-519

[30] A. Mazubert, J. Aubin, S. Elgue, and M. Poux, "Intensification of waste cooking oil transformation by transesterification and esterification reactions in oscillatory baffled and microstructured reactors for biodiesel production," Green Process. Synth., vol. 3, no. 6, pp. 419-429, 2014.

[31] G. da Rocha Filho, D. Brodzki, and G. DjegaMariadassou, "Formation of alkanes, alkylcycloalkanes and alkylbenzenes during the catalytic hydrocracking of vegetable oils," Fuel, vol. 72, no. 4, pp. 543-549, 1993.

[32] M.A. Hazrat, M.G. Rasul, M.M.K. Khan, N. Ashwath, and T.E. Rufford, "Emission characteristics of waste tallow and waste cooking oil based ternary biodiesel fuels," Energy Procedia, vol. 160, pp. 842-847, 2019/02/01/ 2019.

[33] X. Meng, G. Chen, and Y. Wang, "Biodiesel production from waste cooking oil via alkali catalyst and its engine test," Fuel Process. Technol., vol. 89, no. 9, pp. 851-857, 2008.

[34] A.O. Falade, G. Oboh, and A.I. Okoh, "Potential health implications of the consumption of thermallyoxidized cooking oils-a review," Polish J. Food Nutrit. Sci.., vol. 67, no. 2, pp. 95-106, 2017.

[35] I. Karamé, Hydrogenation. BoD-Books on Demand, 2012.

[36] Neste Oil, "NExBTL Diesel," 2012. Available: http://www.nesteoil.com/default.asp?path=1,41,11991, 12243,12335

[37] T. Kalnes, T. Marker, and D.R. Shonnard, "Green diesel: a second generation biofuel," Int. J. Chem. Reactor Eng., vol. 5, no. 1, 2007.

[38] J.A. Petri and T.L. Marker, "Production of diesel fuel from biorenewable feedstocks," Google Patents, 2009.

[39] T.N. Kalnes, K.P. Koers, T. Marker, and D.R. Shonnard, "A technoeconomic and environmental life cycle comparison of green diesel to biodiesel and syndiesel," Environ. Prog. Sustainable Energy, vol. 28, no. 1, pp. 111-120, 2009.

[40] M. Krár et al., "Fuel purpose hydrotreating of vegetable oil on $\mathrm{NiMo} / \gamma-\mathrm{Al} 2 \mathrm{O} 3$ catalyst," Hungarian J. Ind. Chem., vol. 37, no. 2, 2009.

[41] Environmental Leader, "Tyson Foods, Syntroleum partner to turn grease into fuel," 2010. Available: https://www.environmentalleader.com/2010/11/tysonfoods-syntroleum-partner-to-turn-grease-into-fuel/

[42] R. Sotelo-Boyás, F. Trejo-Zárraga, and F. J. Hernández-Loyo, "Hydroconversion of triglycerides into green liquid fuels," Hydrogenation, vol. 338, p. 338, 2012.

[43] Scallan, M. "New renewable diesel plant headed to Norco with federal backing," 2011. Available: https://www.nola.com/news/politics/article_ead3cdd8- a63a-579b-8a27-a4b22df83ad9.html

[44] V. Hachinski et al., "National Institute of Neurological Disorders and Stroke-Canadian stroke network vascular cognitive impairment harmonization standards," Stroke, vol. 37, no. 9, pp. 2220-2241, 2006.

[45] T. Issariyakul, M.G. Kulkarni, A.K. Dalai, and N.N. Bakhshi, "Production of biodiesel from waste fryer grease using mixed methanol/ethanol system," Fuel Process. Technol., vol. 88, no. 5, pp. 429-436, 2007.

[46] C. Mbohwa and A. Mudiwakure, "The status of used vegetable oil (UVO) biodiesel production in South Africa," Proceedings of the World Congress on Engineering. vol I, WCE 2013, July 3 - 5, 2013, London, U.K.

[47] H. Hamze, M. Akia, and F. Yazdani, "Optimization of biodiesel production from the waste cooking oil using response surface methodology," Process Saf. Environ. Prot., vol. 94, pp. 1-10, 2015.

[48] E. Martinez-Guerra and V.G. Gude, "Transesterification of waste vegetable oil under pulse sonication using ethanol, methanol and ethanolmethanol mixtures," Waste Manage., vol. 34, no. 12, pp. 2611-2620, 2014.

[49] O. Awogbemi, E.I. Onuh, and F.L. Inambao, "Comparative study of properties and fatty acid composition of some neat vegetable oils and waste cooking oils," Int. J. Low-Carbon Technol., vol. 14, no. 3, pp. 417-425, 2019.

[50] H. Asli, E. Ahmadinia, M. Zargar, and M.R. Karim, "Investigation on physical properties of waste cooking oil-rejuvenated bitumen binder," Constr. Build. Mater., vol. 37, pp. 398-405, 2012.

[51] S.V. Vassilev, C.G. Vassileva, and V.S. Vassilev, "Advantages and disadvantages of composition and properties of biomass in comparison with coal: An overview," Fuel, vol. 158, pp. 330-350, 2015.

[52] V.V. Thyssen, D.M. Sartore, and E.M. Assaf, "Effect of preparation method on the performance of $\mathrm{Ni} / \mathrm{MgOSiO} 2$ catalysts for glycerol steam reforming," J. Energy Inst., vol. 92, no. 4, pp. 947-958, 2019.

[53] J. Gusmao, D. Brodzki, G. Djéga-Mariadassou, and R. Frety, "Utilization of vegetable oils as an alternative source for diesel-type fuel: hydrocracking on reduced $\mathrm{Ni} / \mathrm{SiO} 2$ and sulphided $\mathrm{Ni}-\mathrm{Mo} / \gamma-\mathrm{Al} 2 \mathrm{O} 3$," Catalysis Today, vol. 5, no. 4, pp. 533-544, 1989.

[54] E. Laurent and B. Delmon, "Study of the hydrodeoxygenation of carbonyl, car $\square$ ylic and guaiacyl groups over sulfided $\mathrm{CoMo} / \gamma-\mathrm{Al} 2 \mathrm{O} 3$ and $\mathrm{NiMo} / \gamma$-Al2O3 catalysts: I. Catalytic reaction schemes," Applied Catalysis A: General, vol. 109, no. 1, pp. 77-96, 1994.

[55] L. Boda, G. Onyestyák, H. Solt, F. Lónyi, J. Valyon, and A. Thernesz, "Catalytic hydroconversion of 
International Journal of Engineering Research and Technology. ISSN 0974-3154 Vol.13, No.3 (2020), pp. 500-519

(C) International Research Publication House. https://dx.doi.org/10.37624/IJERT/13.3.2020.500-519

tricaprylin and caprylic acid as model reaction for biofuel production from triglycerides," Applied Catalysis A: General, vol. 374, no. 1-2, pp. 158-169, 2010.

[56] E. Sari, "Green diesel production via catalytic hydrogenation/decarboxylation of triglycerides and fatty acids of vegetable oil and brown grease," 2013. Dissertation, Wayne State University, https://digitalcommons.wayne.edu/oa_dissertations/79 4

[57] R. McCormick and T. Alleman, "Renewable Diesel Fuel," Golden, CO: National Renewable Energy Laboratory, 2016.

[58] A. F. C. Chart, "National Renewable Energy Laboratory web site," ed.

[59] A. Guzman, J.E. Torres, L.P. Prada, and M.L. Nunez, "Hydroprocessing of crude palm oil at pilot plant scale," Catalysis Today, vol. 156 , no. $1-2$, pp. 38-43, 2010 .

[60] H. Amirmoghadam, M.H. Sadr, H. Aghabozorg, F. Salehirad, and A. Irandoukht, "The effect of molybdenum on the characteristics and catalytic properties of M/Cs $1.5 \mathrm{H} 1.5 \mathrm{PW} 12 \mathrm{O}$ 40/Al $2 \mathrm{O} 3$ $(\mathrm{M}=\mathrm{Ni}$ or/and $\mathrm{Mo})$ nanocatalysts in the hydrocracking of n-decane," React. Kinet. Mech. Catal., vol. 125, no. 2, pp. 983-994, 2018.

[61] D. Kubička, P. Šimáček, and N.J.T.i.C. Žilková, "Transformation of vegetable oils into hydrocarbons over mesoporous-alumina-supported CoMo catalysts," Top. Catal., vol. 52, no. 1-2, pp. 161-168, 2009.

[62] B. Behnejad, M. Abdouss, and A. Tavasoli, "Comparison of performance of $\mathrm{Ni}-\mathrm{Mo} / \gamma$-alumina catalyst in HDS and HDN reactions of main distillate fractions," Pet. Sci., pp. 1-12, 2019.

[63] D. Kubička and L. Kaluža, "Deoxygenation of vegetable oils over sulfided $\mathrm{Ni}, \mathrm{Mo}$ and $\mathrm{NiMo}$ catalysts," Appl. Catal., A, vol. 372, no. 2, pp. 199208, 2010.

[64] Q. Liu, H. Zuo, Q. Zhang, T. Wang, and L. Ma, "Hydrodeoxygenation of palm oil to hydrocarbon fuels over Ni/SAPO-11 catalysts," Chin. J. Catal., vol. 35, no. 5, pp. 748-756, 2014.

[65] M. Servatan et al., "Zeolite-based catalysts for exergy efficiency enhancement: The insights gained from nanotechnology," Mater. Today: Proceedings, vol. 5, no. 7, pp. 15868-15876, 2018.

[66] P.L. Chu, C. Vanderghem, H.L. MacLean, and B.A. Saville, "Process modeling of hydrodeoxygenation to produce renewable jet fuel and other hydrocarbon fuels," Fuel, vol. 196, pp. 298-305, 2017.

[67] A. Galadima and O. Muraza, "Catalytic upgrading of vegetable oils into jet fuels range hydrocarbons using heterogeneous catalysts: A review," J. Ind. Eng. Chem., vol. 29, pp. 12-23, 2015.
[68] R. Sotelo-Boyas, Y. Liu, and T.J.I. Minowa, "Renewable diesel production from the hydrotreating of rapeseed oil with $\mathrm{Pt} / \mathrm{Zeolite}$ and $\mathrm{NiMo} / \mathrm{Al} 2 \mathrm{O} 3$ catalysts," Ind. Eng. Chem. Res., vol. 50, no. 5, pp. 2791-2799, 2010.

[69] D. Kubička, M. Bejblová, and J. Vlk, "Conversion of vegetable oils into hydrocarbons over CoMo/MCM-41 catalysts," Top. Catal., vol. 53, no. 3-4, pp. 168-178, 2010 .

[70] J. Monnier, H. Sulimma, A. Dalai, and G. Caravaggio, "Hydrodeoxygenation of oleic acid and canola oil over alumina-supported metal nitrides," Appl. Catal., A, vol. 382, no. 2, pp. 176-180, 2010.

[71] L. Chen, H. Li, J. Fu, C. Miao, P. Lv, and Z. Yuan, "Catalytic hydroprocessing of fatty acid methyl esters to renewable alkane fuels over Ni/HZSM-5 catalyst," Catal. Today, vol. 259, pp. 266-276, 2016.

[72] J. Xu et al., "Integrated catalytic conversion of waste triglycerides to liquid hydrocarbons for aviation biofuels," J. Cleaner Prod., vol., 222, pp. 784-792, 2019.

[73] J. Chen and Q. Xu, "Hydrodeoxygenation of biodieselrelated fatty acid methyl esters to diesel-range alkanes over zeolite-supported ruthenium catalysts," Catal. Sci. Technol., vol. 6, no. 19, pp. 7239-7251, 2016.

[74] J.-S. Moon and Y.-K. Lee, "Support effects of Ni 2 P catalysts on the hydrodeoxygenation of guaiacol: in situ XAFS studies," Top. Catal., vol. 58, no. 4-6, pp. 211-218, 2015.

[75] Z. He, M. Hu, and X. Wang, "Highly effective hydrodeoxygenation of guaiacol on $\mathrm{Pt} / \mathrm{TiO} 2$ : Promoter effects," Catal. Today, vol. 302, pp. 136-145, 2018.

[76] M. Domínguez-Barroso, C. Herrera, M. Larrubia, and L. Alemany, "Diesel oil-like hydrocarbon production from vegetable oil in a single process over $\mathrm{Pt}$ $\mathrm{Ni} / \mathrm{Al} 2 \mathrm{O} 3$ and $\mathrm{Pd} / \mathrm{C}$ combined catalysts," Fuel Process. Technol., vol. 148, pp. 110-116, 2016.

[77] R. Venter, T. Khethane, L. Radebe, K. Mashamaite, C. Schabort, and S. Marx, "Evaluation of cottonseed oil as co-feedstock for the hydroprocessing of petroleum middle distillates for diesel fuel production," conference $\quad 2016$. https://repository.nwu.ac.za/handle/10394/24989

[78] M.K. Poddar, S. Kumar, P.K. Das, M.R. Maurya, and A.K. Sinha, "Hydroprocessing of aqueous phase of pyrolysis oil over NiMo/Al 2 O $3-\mathrm{SiO} \quad 2$ in microchannel reactor," Catal. Green Chem. Eng., vol. 2, no. 1, 2019.

[79] M. Ameen, M. T. Azizan, S. Yusup, A. Ramli, and M. Yasir, "Catalytic hydrodeoxygenation of triglycerides: An approach to clean diesel fuel production," Renewable Sustainable Energy Rev, vol. 80, pp. 10721088, 2017.

[80] V. Markkanen, P. Lindqvist, E. Harlin, P. Aalto, J. 
International Journal of Engineering Research and Technology. ISSN 0974-3154 Vol.13, No.3 (2020), pp. 500-519

(C) International Research Publication House. https://dx.doi.org/10.37624/IJERT/13.3.2020.500-519

Myllyoja, and V. Alopaeus, "Process for the manufacture of hydrocarbon components," ed: Google Patents, 2015.

[81] J. Myllyoja, P. Aalto, P. Savolainen, V.-M. Purola, V. Alopaeus, and J. Gronqvist, "Process for the manufacture of diesel range hydrocarbons," ed: Google Patents, 2017.

[82] H. Bateni, A. Saraeian, and C. Able, "A comprehensive review on biodiesel purification and upgrading," Biofuel Res. J., vol. 4, no. 3, pp. 668-690, 2017.

[83] Z. Zhang, Q. Wang, H. Chen, and X. Zhang, "Hydroconversion of Waste Cooking Oil into Green Biofuel over Hierarchical USY-Supported NiMo Catalyst: A Comparative Study of Desilication and Dealumination," Catal., vol. 7, no. 10, p. 281, 2017.

[84] S. Abate, G. Giorgianni, P. Lanzafame, S. Perathoner, and G. Centi, "Multifunctional HDO/selective cracking Ni/HBEA catalysts to produce jet fuel and diesel from bio-oils," Chem. Eng. Trans., vol. 50, pp. 259-264, 2016.

[85] R.-X. Chen and W.-C. Wang, "The production of renewable aviation fuel from waste cooking oil. Part I: Bio-alkane conversion through hydro-processing of oil," Renewable Energy, vol. 135, pp. 819-835, 2019.

[86] B. Veriansyah et al., "Production of renewable diesel by hydroprocessing of soybean oil: effect of catalysts," Fuel, vol. 94, pp. 578-585, 2012.

[87] N. Arun, J. Maley, N. Chen, R. Sammynaiken, Y. Hu, and A. K. Dalai, "NiMo nitride supported on $\gamma$-Al2O3 for hydrodeoxygenation of oleic acid: Novel characterization and activity study," Catal. Today, vol. 291, pp. 153-159, 2017.

[88] G. Abdulkareem-Alsultan et al., "Pyro-lytic deoxygenation of waste cooking oil for green diesel production over Ag2O3-La2O3/AC nano-catalyst," J. Anal. Appl. Pyrolysis, vol. 137, pp. 171-184, 2019.

[89] C. Toth, T. Kasza, S. Kovacs, P. Baladincz, and J. Hancsók, "Investigation of catalytic conversion of vegetable oil/gas oil mixtures," in International Petroleum Conference, Bratislava, 2009.

[90] G. W. Huber, S. Iborra, and A. Corma, "Synthesis of transportation fuels from biomass: chemistry, catalysts, and engineering," Chem. Rev., vol. 106, no. 9, pp. 4044-4098, 2006.

[91] G.W. Huber, P. O’Connor, and A. Corma, "Processing biomass in conventional oil refineries: Production of high quality diesel by hydrotreating vegetable oils in heavy vacuum oil mixtures," Applied Catal., A, vol. 329, pp. 120-129, 2007.

[92] B. Valle, A. Remiro, N. García- Gómez, A.G. Gayubo, and J. Bilbao, "Recent research progress on bio- oil conversion into bio- fuels and raw chemicals: a review," J. Chem. Technol. Biotechnol., vol. 94, no.
3, pp. 670-689, 2019.

[93] I. V. Deli et al., "Inhibition of SRGO hydrodesulfurization over $\mathrm{CoMo} / \mathrm{Al} 2 \mathrm{O} 3$ catalyst: comparison of rapeseed oil and carbon monoxide effects," Catal., vol. 23, p. 24, 2017.

[94] S. Tabasso, G. Grillo, D. Carnaroglio, E. Calcio Gaudino, and G. Cravotto, "Microwave-assisted $\gamma$ valerolactone production for biomass lignin extraction: a cascade protocol," Mol., vol. 21, no. 4, p. 413, 2016.

[95] A. Gutierrez, E.-M. Turpeinen, T.-R. Viljava, and O. Krause, "Hydrodeoxygenation of model compounds on sulfided $\mathrm{CoMo} / \gamma-\mathrm{Al} 2 \mathrm{O} 3$ and $\mathrm{NiMo} / \gamma-\mathrm{Al} 2 \mathrm{O} 3$ catalysts; Role of sulfur-containing groups in reaction networks," Catal. Today, vol. 285, pp. 125-134, 2017.

[96] V.O. Gonšalves, S. Brunet, and F. Richard, "Hydrodeoxygenation of cresols over $\mathrm{Mo} / \mathrm{Al} 2 \mathrm{O} 3$ and CoMo/Al 2 O 3 sulfided catalysts," Catal. Lett., vol. 146, no. 8, pp. 1562-1573, 2016.

[97] O. Ayodele, O. S. Togunwa, H.F. Abbas, and W.M.A.W. Daud, "Preparation and characterization of alumina supported nickel-oxalate catalyst for the hydrodeoxygenation of oleic acid into normal and isooctadecane biofuel," Energy Convers. Manage. vol. 88, pp. 1104-1110, 2014.

[98] A. Coumans and E. Hensen, "A real support effect on the hydrodeoxygenation of methyl oleate by sulfided NiMo catalysts," Catal. Today, vol. 298, pp. 181-189, 2017.

[99] K. Jeništová et al., "Hydrodeoxygenation of stearic acid and tall oil fatty acids over Ni-alumina catalysts: Influence of reaction parameters and kinetic modelling," Chem. Eng. J., vol. 316, pp. 401-409, 2017.

[100] H. Nishiumi, "Thermodynamic property prediction for high molecular weight molecules based on their constituent family," Fluid Phase Equilibria, vol. 420, pp. 1-6, 2016.

[101] Y. Sugami, E. Minami, and S. Saka, "Renewable diesel production from rapeseed oil with hydrothermal hydrogenation and subsequent decarboxylation," Fuel, vol. 166, pp. 376-381, 2016.

[102] S. Popov and S. Kumar, "Renewable fuels via catalytic hydrodeoxygenation of lipid-based feedstocks," Biofuels, vol. 4, no. 2, pp. 219-239, 2013.

[103] M.E. Tat, P.S. Wang, J.H. Van Gerpen, and T.E. Clemente, "Exhaust emissions from an engine fueled with biodiesel from high- oleic soybeans," J. Am. Oil Chem. Soc., vol. 84, no. 9, pp. 865-869, 2007.

[104] H. Begum, C. Siwar, A.F. Alam, E.A. Choy, S. Ishak, and L. Alam, "Enhancing sustainability amongst oil palm smallholders in Malaysia," Int. J. Agric. Resour. Governance Ecol., vol. 14, no. 1, pp. 62-79, 2018.

[105] O. Onay and O.M. Koçkar, "Fixed-bed pyrolysis of 
International Journal of Engineering Research and Technology. ISSN 0974-3154 Vol.13, No.3 (2020), pp. 500-519

(C) International Research Publication House. https://dx.doi.org/10.37624/IJERT/13.3.2020.500-519

rapeseed (Brassica napus L.)," Biomass Bioenergy, vol. 26, no. 3, pp. 289-299, 2004.

[106] R. Venter, J. Booysen, S. Marx, and C. Schabort, "Evaluation of bio-char based products as hydrotreating catalysts for the production of renewable fuel," $2017 . \quad$ Available: https://repository.nwu.ac.za/handle/10394/26683

[107] G. Duman, C. Okutucu, S. Ucar, R. Stahl, and J. Yanik, "The slow and fast pyrolysis of cherry seed," Bioresour. Technol., vol. 102, no. 2, pp. 1869-1878, 2011.

[108] A. Srifa, K. Faungnawakij, V. Itthibenchapong, and S. Assabumrungrat, "Roles of monometallic catalysts in hydrodeoxygenation of palm oil to green diesel," Chem. Eng. J., vol. 278, pp. 249-258, 2015.

[109] M. Gousi et al., "Green diesel production over nickelalumina co-precipitated catalysts," Applied Catalysis, A., vol. 536, pp. 45-56, 2017.

[110] E.S. Perez-Cisneros, M. Sales-Cruz, R. LoboOehmichen, and T. Viveros-García, "A reactive distillation process for co-hydrotreating of non-edible vegetable oils and petro-diesel blends to produce green diesel fuel," Comput. Chem. Eng., vol. 105, pp. 105$122,2017$.

[111] V. Kumar, R.K. Sindhu, and S. Kumar, "Comparative analysis of green diesel versus petro-diesel in compression ignition engine," Biosci. Biotechnol. Res. Commun, vol. 11, pp. 128-135, 2018.

[112] L.M. Orozco, D.A. Echeverri, L. Sánchez, and L.A. Rios, "Second-generation green diesel from castor oil: Development of a new and efficient continuousproduction process," Chem. Eng. J. vol. 322, pp. 149156, 2017.

[113] E. Kordouli, B. Pawelec, K. Bourikas, C. Kordulis, J.L.G. Fierro, and A. Lycourghiotis, "Mo promoted $\mathrm{Ni}-\mathrm{A} 12 \mathrm{O} 3$ co-precipitated catalysts for green diesel production," Applied Catalysis, B., vol. 229, pp. 139154, 2018.

[114] T. Kalnes, T. Marker, D. Shonnard, and K. Koers, "Green diesel and biodiesel: A technoeconomic and life cycle comparision," in 1st Alternative Fuels Technology Conference, Prague, Czechoslovakia, 2008, vol. 18.

[115] M.F. Othman, A. Adam, G. Najafi, and R. Mamat, "Green fuel as alternative fuel for diesel engine: A review," Renewable Sustainable Energy Rev, vol. 80, pp. 694-709, 2017.

[116] J.K. Mwangi, W.-J. Lee, Y.-C. Chang, C.-Y. Chen, and L.-C. Wang, "An overview: Energy saving and pollution reduction by using green fuel blends in diesel engines," Applied Energy, vol. 159, pp. 214236, 2015.

[117] S.K. Bej, "Performance evaluation of hydroprocessing catalysts A review of experimental techniques,"
Energy Fuels, vol. 16, no. 3, pp. 774-784, 2002.

[118] G.W. Huber and A. Corma, "Synergies between bioand oil refineries for the production of fuels from biomass," Angewandte Chemie International Edition, vol. 46, no. 38, pp. 7184-7201, 2007.

[119] M. Tripathi, J.N. Sahu, and P. Ganesan, "Effect of process parameters on production of biochar from biomass waste through pyrolysis: A review," Renewable Sustainable Energy Rev, vol. 55, pp. 467481, 2016.

[120] N. Muradov and T. Veziroğ lu, "From hydrocarbon to hydrogen-carbon to hydrogen economy," Int. J. Hydrogen Energy, vol. 30, no. 3, pp. 225-237, 2005.

[121] A. Konieczny, K. Mondal, T. Wiltowski, and P. Dydo, "Catalyst development for thermocatalytic decomposition of methane to hydrogen," Int. J. Hydrogen Energy, vol. 33, no. 1, pp. 264-272, 2008.

[122] M. Balat and M. Balat, "Political, economic and environmental impacts of biomass-based hydrogen," Int. J. Hydrogen Energy, vol. 34, no. 9, pp. 3589-3603, 2009.

[123] J.D. Holladay, J. Hu, D.L. King, and Y. Wang, "An overview of hydrogen production technologies," Catal. Today, vol. 139, no. 4, pp. 244-260, 2009.

[124] S.H. Oelofse, A.P. Muswema, and R. Koen, "The changing face of waste management-considerations when conducting a waste characterisation study," 2016. Available:

https://researchspace.csir.co.za/dspace/handle/10204/8 948

[125] J.A. Turner, "Sustainable hydrogen production," Science, vol. 305, no. 5686, pp. 972-974, 2004.

[126] P.F. Peterson, C.W. Forsberg, and P. Pickard, "Advanced CSiC composites for high-temperature nuclear heat transport with helium, molten salts, and sulfur-iodine thermochemical hydrogen process fluids," in Second Information Exchange Meeting on Nuclear Production of Hydrogen, Argonne National Laboratory, Illinois, USA, 2003, pp. 2-3.

[127] O. Khaselev and J.A. Turner, "A monolithic photovoltaic-photoelectrochemical device for hydrogen production via water splitting," Science, vol. 280, no. 5362, pp. 425-427, 1998.

[128] M. Dresselhaus and I. Thomas, "Alternative energy technologies," Nature, vol. 414, no. 6861, p. 332, 2001.

[129] N.S. Lewis, "Light work with water," Nature, vol. 414, no. 6864, p. 589, 2001.

[130] O. Khaselev, A. Bansal, and J. Turner, "Highefficiency integrated multijunction photovoltaic/electrolysis systems for hydrogen production," Int. J. Hydrogen Energy, vol. 26, no. 2, pp. 127-132, 2001. 
International Journal of Engineering Research and Technology. ISSN 0974-3154 Vol.13, No.3 (2020), pp. 500-519

(C) International Research Publication House. https://dx.doi.org/10.37624/IJERT/13.3.2020.500-519

[131] P. Nikolaidis and A. Poullikkas, "A comparative overview of hydrogen production processes," Renewable Sustainable Energy Rev, vol. 67, pp. 597$611,2017$.

[132] A. Lawal, J. Manganaro, B. Goodall, and R. Farrauto, "Pt-based Bi-metallic monolith catalysts for partial upgrading of microalgae oil," Stevens Inst. of Technology, Hoboken, NJ (United States) 2015.

[133] H. Pourbafrani, "Life cycle and techno-economic analysis of Fischer-Tropsch renewable diesel and jet fuel production," $2016 . \quad$ Available: https://tspace.library.utoronto.ca/handle/1807/91257

[134] K. Hengst, M. Arend, R. Pfützenreuter, and W.F. Hoelderich, "Deoxygenation and cracking of free fatty acids over acidic catalysts by single step conversion for the production of diesel fuel and fuel blends," Applied Catalysis B., vol. 174, pp. 383-394, 2015.

[135] B. Donnis, R.G. Egeberg, P. Blom, and K.G. Knudsen, "Hydroprocessing of bio-oils and oxygenates to hydrocarbons. Understanding the reaction routes," Topics Catal., vol. 52, no. 3, pp. 229-240, 2009.

[136] S. Bezergianni, A. Dimitriadis, A. Kalogianni, and P.A. Pilavachi, "Hydrotreating of waste cooking oil for biodiesel production. Part I: Effect of temperature on product yields and heteroatom removal," Bioresour. Technol., vol. 101, no. 17, pp. 6651-6656, 2010.

[137] S. Bezergianni, A. Dimitriadis, A. Kalogianni, and K. G. Knudsen, "Toward hydrotreating of waste cooking oil for biodiesel production. Effect of pressure, H2/oil ratio, and liquid hourly space velocity," Ind. Eng. Chem. Res. vol. 50, no. 7, pp. 3874-3879, 2011.

[138] T. Sankaranarayanan, M. Banu, A. Pandurangan, and S. Sivasanker, "Hydroprocessing of sunflower oil-gas oil blends over sulfided $\mathrm{Ni}-\mathrm{Mo}-\mathrm{Al}-$ zeolite beta composites," Bioreource Technol., vol. 102, no. 22, pp. 10717-10723, 2011.

[139] Z. Fang, Liquid, Gaseous and Solid Biofuels: Conversion Techniques. BoD-Books on Demand, 2013.

[140] S. Bezergianni and A. J. Kalogianni, "Hydrocracking of used cooking oil for biofuels production," Bioreource Technol., vol. 100, no. 17, pp. 3927-3932, 2009.

[141] M. Jha, A. K. Sinha, and P. Agnihotri, "Hydroprocessing of Jatropha oil to produce green fuels," Int. J. ChemTech Res., vol. 5, no. 2, pp. 765$770,2013$. 